\title{
MULTIPLE LAYERS OF GENDER DIVERSITY ON CORPORATE BOARDS: TO FORCE OR NOT TO FORCE?
}

\author{
JeAn du PLessis*
}

JAMES O'SUllivan ${ }^{* *}$

\section{RUTH RENTSCHLER ${ }^{* * *}$}

This article examines diversity on corporate boards, focusing on gender diversity and taking both contemporary and historical perspectives. Australia forms a particular focus of the article but, as far as mandatory quota legislation is concerned, other jurisdictions provide comparisons. The authors illustrate how Australian corporate board gender diversity is starting from a low base in contrast to some other types of boards. Arguments for and against more women on boards are analysed in order to provide a comprehensive examination of extant research. The article also examines briefly whether a business case can be made for board gender diversity within the wider framework of board diversity. The authors acknowledge that there are unanswered questions about the right gender balance on boards and whether, without mandatory quota legislation, a voluntary system can achieve best practice targets. They explore the notion of critical mass - the idea that, upon female board representation reaching approximately 15 per cent, efforts to further redress the imbalance may lose momentum. Their conclusion is that, in the Australian jurisdiction, progress is being made belatedly towards increasing gender diversity on corporate boards. However, substantial challenges are envisaged if significant progress is not made imminently to increase the number of women serving on corporate boards.

\footnotetext{
* PProc, LLB, LLM, LLD (UOFS), Professor, School of Law, Deakin University.

${ }^{* *}$ BComLaw (University of Adelaide), CA, MBA (Law) (Deakin University).

*** OAM, BA Hons (Melb), PhD (Monash), Professor, School of Management and Marketing, Deakin University.
} 


\section{INTRODUCTION}

This article asks whether diversity of corporate board membership is desirable and how that diversity can best be achieved. While recognising that diversity is broader than gender diversity, this article focuses on gender debates, providing a framework for analysis of a topical issue. The authors take the view that board gender diversity represents both governance and community expectations but that change is progressing slowly in Australia. Hence, arguments are presented both for and against board gender diversity, presenting the state of play, while also disclosing the authors' position that board gender diversity brings greater heterogeneity to boards which aids decision-making. The authors set the article within the Australian context but provide international comparisons and a historical framework. While the focus is on corporate board gender diversity, the authors provide examples from other domains, such as the not-for-profit, university and government sectors. Their conclusion is that while, in the Australian jurisdiction, progress is being made on board gender diversity, there is still a long way to go. In a voluntary system such as Australia's increases in diversity have occurred belatedly, recently and from a low base. This article is timely given the release of the Women on Boards' Guidelines for Gender Balance Performance and Reporting Australia ${ }^{1}$ which outline five key points on how all types of organisations can improve career opportunities for women that will lead to more women being available for board positions. The Guidelines provide a framework that encourages cultural change in public and private entities. While adoption of the Guidelines is voluntary, it is envisaged that they will be used for corporate governance reporting to shareholders in annual reports. In brief, the Guidelines recommend collecting and reporting data on women in the workplace and their training and development for leadership positions. ${ }^{2}$ While it might be argued that no new insights on gender diversity on boards are provided by the Guidelines, they underscore the urgency of the issue in today's world.

\footnotetext{
${ }^{1}$ Stephanie Quine, Gender Balance Guidelines Launched (3 May 2013) Lawyers Weekly $<$ http://www.lawyersweekly.com.au/news/gender-balance-guidelines-launched>. See also Women on Boards Guidelines Development Committee, Guidelines for Gender Balance Performance and Reporting Australia (May 2013) <http://womenonboards.org.au/pubs/ guidelines/>. The Guidelines Development Committee was formed with the initiative of Women on Boards and includes Chartered Secretaries Australia, Financial Services Institute of Australia, Stockland, UGM Consulting, Women’s Lawyers Association of Queensland Inc, and Women on Boards.

${ }^{2}$ Women on Boards Guideline Development Committee, above n 1.
} 


\section{Diversity DEFINED}

Social diversity is the result of the interaction of the numerous human attributes differentiating individuals and groups. Castania suggests that

[i]mplicit in this definition [of diversity] is the awareness of our group identities as well as our individual differences. We are unique as individuals, while our group identities determine our historical inclusion or exclusion. We often see ourselves only as individuals, even though historically we have been treated based on our group identities. ${ }^{3}$

Similarly, 'diversity' at board level encompasses a number of human attributes, of which gender is but one. The United States Department of Agriculture Strategic Planning Task Force on Diversity provides the following definition: '[D]iversity is differences among people with respect to age, class, ethnicity, gender, physical and mental ability, race, sexual orientation, spiritual practice, and other human attributes. ${ }^{4}$ Nonetheless, the board diversity debate is dominated by gender — both in Australia and abroad. ${ }^{5}$

\section{ARgumEnTS AgAinst BoARd Gender Diversity}

Arguments against board gender diversity are outlined briefly below, while noting that they are susceptible to several counter-arguments:

\section{A The Reverse Causation Argument}

It is argued that strong corporate performance leads to increased board diversity, rather than diverse boards achieving improved corporate

3 Kathy Castania, Diversity: What is Diversity? (Cornell University, 1996) 2 $<$ http://extension.usu.edu/diversity/files/uploads/diversity704.pdf $>$.

${ }^{4}$ Strategic Planning Task Force on Diversity - Cooperative State Research, Education, and Extension Service, Pathway to Diversity: Strategic Plan for the Cooperative Extension System's Emphasis on Diversity (Washington, DC, October 1991), cited in Castania, above n $3,2$.

${ }^{5}$ See, eg, Jo Armstrong and Sylvia Walby, European Parliament, Directorate-General for Internal Policies - Policy Department C: Citizens' Rights and Constitutional Affairs, Gender Quotas in Management Boards (2012) 4 <http://www.europarl.europa.eu/ committees/en/JURI/studiesdownload.html?languageDocument=EN\&file=66951>; Vanessa Anastasopoulos, David A H Brown and Debra L Brown, Women On Boards: Not Just the Right Thing ... But the 'Bright' Thing (May 2002) The Conference Board of Canada, 3 $<$ http://www.conferenceboard.ca/e-library/abstract.aspx?did=374>. 
performance: this occurrence is referred to as 'reverse causation' ${ }^{6}$ Whilst the application of reverse causation is specific to gender diversity, the extension of the noted arguments to other elements of diversity is not unreasonable. Studies have revealed that successful corporations tend to appoint more female directors and several studies have addressed this notion directly. An example is Farrell and Hersch, ${ }^{7}$ who studied a sample of between 266 and 300 Fortune 500 and Service 500 firms between 1990 and 1999. Their study revealed that firms achieving strong profit results or return on assets appointed more female directors. ${ }^{8}$ Adams and Ferreira concluded that, '[a]lthough a positive relation between gender diversity in the boardroom and firm performance is often cited in the popular press, it is not robust to any of our methods of addressing the endogeneity of gender diversity'. ${ }^{9}$ Dobbin and Jung's later research supported the finding of Adams and Ferreira 'that the cross-sectional positive relationship found between board diversity and corporate performance is likely spurious - a consequence of reverse causation'. ${ }^{10}$

\section{B The Post Hoc Ergo Propter Hoc Fallacy}

'After this, therefore because of this' is a fallacy of reasoning that correlation proves causation. ${ }^{11}$ All other things being equal, a result following an action (with identified correlation) is insufficient to prove that the result is caused by the action (causation). Unless all other variables can be identified and controlled, it may be unreasonable to conclude that a corporation's improved performance has been achieved as a result of recruiting a more diverse board. Because of the innumerable variables impacting upon the performance of corporations, concluding that a diverse board improves corporate performance is hence difficult.

\footnotetext{
${ }^{6}$ Frank Dobbin and Jiwook Jung, 'Corporate Board Gender Diversity and Stock Performance: The Competence Gap or Institutional Investor Bias?’ (2011) 89 North Carolina Law Review 809, 819.

${ }^{7}$ Kathleen Farrell and Philip Hersch, 'Additions to Corporate Boards: The Effect of Gender' (2005) 11 Journal of Corporate Finance 85, 90.

${ }^{8}$ Ibid 86.

${ }^{9}$ Renee Adams and Daniel Ferreira, 'Women in the Boardroom and their Impact on Governance and Performance' (2009) 94 Journal of Financial Economics 308, 308 quoted in Dobbin and Jung, above n 6, 820.

${ }^{10}$ Dobbin and Jung, above n 6, 820.

${ }^{11}$ US Legal Definitions, Post Hoc Ergo Propter Hoc Law and Legal Definition (2012) US Legal <http://definitions.uslegal.com/p/post-hoc-ergo-propter-hoc/>.
} 
Similarly, the sibling maxim cum hoc ergo propter hoc, meaning 'with this, therefore because of this', is also a fallacy of reasoning: two things occurring together do not necessarily have a cause-and-effect relationship. ${ }^{12}$ This argument has also been applied to board diversity to assert that improved profits may not be caused by an increase in female directorships. ${ }^{13}$

\section{Tokenism}

'Tokenism' refers to situations where the interests of minority groups are promoted for political reasons rather than diversity being embraced as an opportunity, with all talent sources being considered with a view to recruiting the most effective mix of qualified individuals. In cases of 'token representation', minority group representatives 'face expectations that make it difficult to perform to their potential' and 'face pressures that may adversely affect their performance', such as additional scrutiny from majority members and the perception that their position is one of representation and not one based upon individual merit. ${ }^{14}$

\section{Stereotype-threat}

Research suggests that 'experimental manipulation' to increase the prominence of minority group representation may have negative repercussions on the performance of minority members (and in turn the board and the corporation). ${ }^{15}$ Based on the fact that more diverse views need to be taken into consideration it becomes harder to develop strategy and to make board

\footnotetext{
${ }^{12}$ David Hackett Fischer, Historians' Fallacies: Toward a Logic of Historical Thought (Harper \& Row, 1970) 167-9. See further Crystal A Gadegbeku and Glenn M Chertow, 'Cum Hoc Ergo Propter Hoc: Health Disparities Real and Imagined' (2009) 4(2) Clinical Journal of the American Society of Nephrology $251<$ http://cjasn.asnjournals.org/content/4/2/251.full>; John Aldrich, 'Correlations Genuine and Spurious in Pearson and Yule' (1995) 10(4) Journal of Statistical Science 364, 364-76 <http://www.economics.soton.ac.uk/staff/aldrich/spurious. pdf $>$.

${ }^{13}$ Siri Terjesen, Ruth Sealy and Val Singh, 'Women on Corporate Boards: A Review and Research Agenda' (2009) 17 Corporate Governance: An International Review 320, 334.

14 Barbara F Reskin, Debra B McBrier and Julie A Kmec, 'The Determinants and Consequences of Workplace Sex and Race Composition' (1999) 25 Annual Review of Sociology 335, 347-9; see also Rosabeth Moss Kanter, Men and Women of the Corporation (Basic Books, 1977) 210-12, referred to in Dobbin and Jung, above n 6, 816.

15 Claude M Steele and Joshua Aronson, 'Stereotype Threat and the Intellectual Test Performance of African Americans' (1995) 69(5) Journal of Personality and Social Psychology 797, 798-9, cited in Dobbin and Jung, above n 6, 817.
} 
decisions. The influence of experimental manipulation and stereotypes makes minority group representatives feel they are being judged as a group rather than as individuals, thus reducing performance. ${ }^{16}$

\section{E Problem-Solving Efficacy}

Some scholars contend that '[m]ixed gender and racial groups may divide, and diversity may elicit group conflict that interferes with efficacy. Diversity in race, ethnicity, and, to a lesser extent, sex, tends to bring about group conflict, hinder communication, and interfere with cooperation, thereby lowering performance'. ${ }^{17}$ Research analysing the impact of diverse boards on corporate performance - via the diminished interaction and problem-solving of a diverse group - is largely divided as studies have produced inconclusive and inconsistent results. ${ }^{18}$

\section{F Research Evidence that Performance Is Unrelated to Diversity}

Adams and Ferreira and Dobbin and Jung rebuff conclusions made on the basis of previous studies indicating a causal link between gender diversity and performance. They state that those studies 'cannot be "given causal interpretations" because they did not account for endogeneity - inclusion of which likely would have resulted in a negative effect'. ${ }^{19}$ Farrell and Hersch's study of between 266 and 300 Fortune 500 and Service 500 firms over 10 years from 1990 to 1999 revealed 'reverse causation' and the appointment of female directors by companies experiencing a successful period. ${ }^{20}$ Farrell and Hersch concluded that, following their appointment, 'female directors do not affect [the corporation's] subsequent performance'. ${ }^{21}$ Adams and Ferreira went even further than this, noting that, after appointment, 'female directors have subsequent negative effects'. ${ }^{22}$ Dobbin and Jung conceded that ' $[t]$ he

\footnotetext{
${ }^{16}$ Ibid.

${ }^{17}$ See generally Katherine Y Williams and Charles A O’Reilly III, 'Demography and Diversity in Organizations: A Review of 40 Years of Reasearch' (1998) 20 Research in Organizational Behaviour 77, cited in Dobbin and Jung, above n 6, 816.

${ }^{18}$ Terjesen, Sealy and Singh, above n 13, 324.

${ }^{19}$ Adams and Ferreira, above n 9, 292, 306, cited in Dobbin and Jung, above n 6, 810, 817.

${ }^{20}$ Farrell and Hersch, above n 7, 85, cited in Dobbin and Jung, above n 6, 819.

${ }^{21}$ Ibid.

${ }^{22}$ Adams and Ferreira, above n 9, 308, cited in Dobbin and Jung, above n 6, 819-20.
} 
negative effects found in certain studies may be real', and hypothesised 'a new mechanism to explain this effect: shareholder bias'. ${ }^{23}$

\section{G Dobbin and Jung's 'Institutional Bias' Theory for Male Board Domination}

Dobbin and Jung's 2011 theory of 'institutional investor bias' (or shareholder bias) suggests that corporations may suffer share price reductions as a result of taking progressive action on gender diversity. ${ }^{24}$ In this view, sharemarket performance is equated to corporate performance. Dobbin and Jung hypothesised that the control wielded by institutional investors, as major players in equities markets, directly affected company share prices and that gender bias drove some of their strategic decisions. ${ }^{25}$ Institutional investors held 80 per cent of the shares in the largest companies of Dobbin and Jung's sample, ${ }^{26}$ which reflected American shareholding at the time. ${ }^{27}$ Their research considered, among several hypotheses, the impact of board gender composition on the buy and sell decisions of institutional investors. ${ }^{28}$ As active traders, institutional investors develop buy and sell strategies, with concern for matters such as in changes in board composition. ${ }^{29}$ Dobbin and Jung cited survey results concluding that investors generally believe that 'women lack the human capital and business experience to be board members', hypothesizing that 'investors may react negatively to firms that appoint women board members' ${ }^{30}$ They discovered that 'institutional investors do promote gender diversity on boards through shareholder proposals favoring diversity'. ${ }^{31}$ Their findings noted that increases in board

\footnotetext{
${ }^{23}$ Dobbin and Jung, above n 6, 820.

${ }^{24}$ Ibid 811, 820.

${ }^{25}$ Ibid 820-5.

${ }^{26}$ Ibid 825-6.

${ }^{27}$ Ibid 836.

${ }^{28}$ Ibid 822.

${ }^{29}$ See Michael Useem, Investor Capitalism: How Money Managers Are Changing the Face of Corporate America (Basic Books, 1996) 209; Diane Del Guercio and Jennifer Hawkins, 'The Motivation and Impact of Pension Fund Activism' (1999) 52 Journal of Financial Economics 293; Stuart L Gillan and Laura T Sparks, 'Corporate Governance Proposals and Shareholder Activism: The Role of Institutional Investors' (2000) 57 Journal of Financial Economics 275, 284; Sunil Wahal, 'Pension Fund Activism and Firm Performance' (1996) 31 Journal of Financial and Quantitative Analysis 1, 9, cited in Dobbin and Jung, above n 6, 817.

${ }^{30}$ Dobbin and Jung, above n 6, 822.

${ }^{31}$ Ibid 828.
} 
gender diversity do not affect subsequent profitability. However, critically, Dobbin and Jung's study revealed that, despite stable profits, 'an increase in gender diversity on boards is followed by a significant decrease in stock value'. ${ }^{32}$ This observation lends credence to the hypothesis that 'institutional investors may sell the stock of firms that appoint women to their boards not because profits suffer, but because they are biased against women' ${ }^{33}$

\section{ARgumENTS IN FAVOUR OF BOARD GENDER DIVERSITY}

Some arguments in favour of board gender diversity are outlined briefly below.

\section{A Board Gender Diversity Leads to Better Corporate Performance}

It is argued that, by considering all sources of talent in the recruitment of board directors, progressive corporations with enlightened approaches to diversity achieve improved performance. ${ }^{34}$ The Institute of Directors in Ireland believes that the need for gender diversity is

just one element of a broader need for diversity in the boardroom which is of paramount importance to the leadership and success of a business and its interests. Diversity should not just be about ensuring the presence of female

\footnotetext{
${ }^{32}$ Ibid (emphasis added).

${ }^{33}$ Ibid.

${ }^{34}$ Corporations and Markets Advisory Committee (CAMAC), Diversity on Boards of Directors Report (March 2009) 51 <http://www.camac.gov.au/camac/camac. nsf/byHeadline/ PDFFinal+Reports+2009/\$file/Board_Diversity_B5.pdf>; Lois Joy et al, The Bottom Line: Corporate Performance and Women's Representation on Boards (2007) Catalyst, 1 $<$ http://www.catalyst.org/knowledge/bottom-line-corporate-performance-and-womensrepresentation-boards>. See also David A Carter et al, 'The Gender and Ethnic Diversity of US Boards and Board Committees and Firm Financial Performance' (2010) 18(5) Corporate Governance An International Review 396, 410-11; Niclas L Erhardt, James D Werbel and Charles B Shrader, 'Board of Director Diversity and Firm Financial Performance' (2003) 11(2) Corporate Governance: An International Review 102, 107, cited in Dobbin and Jung, above n 6, 809. Deloitte, Board Effectiveness Corporate Australia: Bridging the Gender Divide (2010) 3 <http://www.deloitte.com/assets/Dcom-Tanzania/Local\%20Assets/ Documents/Deloitte\%20Article_Women\%20in\%20the\%20boardroom.pdf>; Forbes Insights, Diversity and Inclusion: Unlocking Global Potential: Global Diversity Rankings by Country, Sector and Occupation (2012) <http://www.forbes.com/forbesinsights/diversity_2012/>.
} 
directors, it encompasses much more than that, everything from the skills and expertise of directors to their level of independence from the company, to their age and nationality. ${ }^{35}$

Numerous studies have linked diverse boards with improved share prices and profitability, with the majority of research focusing upon the dominant board diversity issue: gender. ${ }^{36}$ In 2007, Catalyst, 'a leading non-profit organization with a mission to expand opportunities for women and business, ${ }^{37}$ performed a detailed research study which considered the impact of gender diversity on company boards. It was noted that companies with 'more female board representatives' outperformed those with 'the least' female board representatives on each of the following key financial indicators: return on equity (by 53 per cent), return on sales (by 42 per cent), and return on invested capital (by 66 per cent). ${ }^{38}$

Theoretically, a board representing diverse societal interests achieves improved levels of strategic thinking and risk management. This view is supported in the literature. In a 2002 study, the Conference Board of Canada pointed out the advantages of a diverse board, which included representatives of diverse company owners and stakeholders. ${ }^{39}$ It stated that such a board makes better strategic decisions as it is better equipped to rely on diverse views to manage risk and improve strategic planning. ${ }^{40}$ Maura Quinn of the Institute of Directors in Ireland is also supportive of board diversity, noting that critical questions are asked by a diverse board and that 'diversity brings a range of perspectives to discussions, helping to avoid the group-think mentality which has been seen in some boards in recent years'. ${ }^{41}$ In Deloitte's 2010 document, Board Effectiveness: Corporate Australia: Bridging the Gender Divide, Liselott Kilaas, in the foreword, acknowledges the 'evolving role of the corporate board' and the significant increase in the 'scope of the

${ }^{35}$ Maura Quinn, Submission in Respect of Consultation on Gender Imbalance in Corporate Boards in the EU (25 May 2012) Institute of Directors in Ireland, $2<$ http://ec.europa. eu/justice/newsroom/gender-equality/opinion/files/120528/all/188_en.pdf>.

${ }^{36}$ See, eg, Dobbin and Jung, above n 6, 809.

37 Catalyst is an organisation 'dedicated to creating more inclusive workplaces where employees representing every dimension of diversity can thrive': Catalyst, Who We Are (2013) <http://www.catalyst.org/who-we-are> .

${ }^{38}$ Joy et al, above n 34.

${ }^{39}$ See Anastasopoulos, Brown and Brown, above n 5; Quinn, above n 35. See also Deloitte, above $n 34$.

${ }^{40}$ Anastasopoulos, Brown and Brown, above n 5, 3.

${ }^{41}$ Quinn, above n 35, 5. 
board's oversight' in calling for 'a broader skillset and wider perspective in the board. Again, there is an implied need for more board diversity’ ${ }^{42}$

\section{B Board Gender Diversity Affects Problem-Solving, Teamwork and Decision-Making}

Many extend the argument, proposing that a diverse board affects problemsolving efficacy, ${ }^{43}$ leading to improved corporate performance. ${ }^{44}$ Research suggests that groups with occupational diversity are more effective at problem-solving than those without diversity (homogeneous groups). ${ }^{45}$ Furthermore, personality diversity amongst teams improves efficacy by broadening discussions, thus avoiding group-think. In addition, studies found that team work is improved when at critical mass (which is generally considered to be 15 per cent or more ${ }^{46}$ and another study has found that having three or more women on a board can change the dynamics and lead to improved performance. ${ }^{47}$ Whilst conceding that correlation does not prove causation, Thomson and Lloyd conclude that '[i]t seems fair to say that insofar as the business case for appointing more women to boards is provable, it is proven'. ${ }^{48}$ Despite these arguments, and whilst research is not conclusive,

\footnotetext{
${ }^{42}$ Deloitte, above $n 34$.

${ }^{43}$ Karen A Bantel and Susan E Jackson, 'Top Management and Innovations in Banking: Does the Composition of the Top Team Make a Difference?' (1989) 10 Strategic Management Journal 107, 111, 114, 118, cited in Dobbin and Jung, above n 6, 814. See also Donald C Hambrick, Theresa Seung Cho and Ming-Jer Chen, 'The Influence of Top Management Team Heterogeneity on Firms' Competitive Moves’ (1996) 41(4) Administrative Science Quarterly 659, 680.

${ }^{44}$ Joy et al, above $n$ 34. See also Carter et al, above n 34, 410-11; Erhardt et al, above n 34, in Dobbin and Jung above n 6, 809-10. See generally CAMAC, above n 34; Deloitte, above n 34; Forbes Insights, above n 34.

${ }^{45}$ Bantel and Jackson, above n 43, 107, 111, 114, 118, cited in Dobbin and Jung, above n 6, 814.

${ }^{46}$ Joy et al, above $n 34$.

${ }^{47}$ Alison M Konrad, Vicki Kramer and Sumru Erkut, 'Critical Mass: The Impact of Three or More Women on Corporate Boards' (2008) 37 Organizational Dynamics 145, 145 ff; Jeremy Galbreath, 'Are There Gender-Related Influences on Corporate Sustainability? A Study of Women on Boards of Directors' (211) 17 Journal of Management \& Organization 17, 18, 25.

${ }^{48} \mathrm{P}$ Thomson and T Lloyd, 'Women and the New Business Leadership' (Palgrave Macmillan, 2011), quoted in Armstrong and Walby, above n 5, 34.
} 
evidence indicative of a correlation between board gender diversity, problemsolving, team work, and decision-making has been identified. ${ }^{49}$

\section{Causal Link between Female Leadership and Corporate Performance}

Studies have suggested a correlation between female leadership and corporate performance. $^{50}$

[T]he Forbes 2010 'World’s 100 Most Powerful Women’ issue, [conducted] a study of the stock performance of the 26 publicly traded companies run by women on the list [and] discovered that, as a group, they outperformed the market, where most companies were run by male CEOs. On average, the 26 companies beat the market by $28 \%$ and their respective industries by $15 \%{ }^{51}$

Despite such conclusions being open to counter-arguments, Forbes' conclusions are supported by many business leaders. An example is Jane Diplock who, in the foreword to Deloitte's Women in the Boardroom: A Global Perspective, stated that 'business should see that this issue [gender diversity] is no longer about equal opportunity, or even merely a matter of choice. It is clearly a matter of good governance'. ${ }^{52}$ Liselott Kilaas, in the same foreword, noted that ' $[\mathrm{m}]$ ore women should sit on boards because of the evolving role of the corporate board ... [and] ... because board diversity is required more than ever'. ${ }^{53}$ Elizabeth Broderick stated in a speech that '[t]he research correlates increased corporate performance with greater gender diversity at the senior level. Companies with better gender diversity at the senior levels, do better'. ${ }^{54}$ Women like Elizabeth Broderick, in leadership positions in peak bodies, have acted as change agents, providing a voice for women seeking to obtain board positions while recognising the danger that

\footnotetext{
${ }^{49}$ Yi Wang and Bob Clift, 'Is There a "Business Case” for Board Diversity?' (2009) 21 Pacific Accounting Review 88, 89-91; Jean J du Plessis, Ingo Saenger and Richard Foster, 'Board Diversity or Gender Diversity? Perspectives from Europe, Australia and South Africa' (2012) 17 Deakin Law Review 207, 242-3.

${ }^{50}$ See above $n 34$.

${ }^{51}$ Forbes Insights, above n 34, 4, 8.

${ }^{52}$ Deloitte, above n 34, 2.

${ }^{53}$ Ibid 3.

${ }^{54}$ Elizabeth Broderick, 'Getting on Board: Quotas and Gender Equality' (Speech delivered at 'Gender Matters', the third Women on Boards Conference, Sheraton on the Park, Sydney, 29 April 2011) <http://www.hreoc.gov.au/about/media/speeches/sex_discrim/2011/20110429_ women_boards.html>.
} 
such reform may stall. As noted by Broderick in April 2011, '[a] window of opportunity to achieve critical mass has opened over the last 18 months' as a result of Australia's rapid improvement in female board representatives on listed companies. ${ }^{55}$ Given the rate of progress, Broderick predicted that '[o]ver the next 12 months we will most likely progress to around 15\% of women on ASX [Australian Securities Exchange] 200 boards'.$^{56}$ Indeed, during 2012, Australia reached 15 per cent female representation on ASX 200 boards and, as at 28 May 2014, the rate was 18.2 per cent. ${ }^{57}$ Upon the rate of female representation reaching levels of around 15 per cent there exists the risk that 'the pace of change will slow and the pressure for change will reduce'. ${ }^{58}$ Broderick pointed out that this was the experience of the United States (US) where the number of women on the boards of Fortune 500 companies has remained at 15 per cent for over a decade and she argued that we should not allow this to happen in Australia. ${ }^{59}$ Indeed, business leaders increasingly support the notion that for a nation to achieve global success it must utilise and develop its female talent. ${ }^{60}$ The European Commissioner, Michel Barnier, states that 'it's not only a question of fairness. The presence of women in the leadership of a country or a region or a business is a question of good governance'. ${ }^{61}$

\section{Corporate Boards should Reflect Different Diversity Paradigms}

Some scholars argue that corporate boards should reflect the composition of the community and its demographic make-up for three reasons: to avoid discrimination; for fairness, equity and access; and for the promotion of learning and effectiveness. ${ }^{62}$ Fairness and the avoidance of discrimination are

\footnotetext{
55 Ibid.

56 Ibid.

${ }^{57}$ Australian Institute of Company Directors (AICD), Statistics: Appointments to S\&P/ASX 200 Boards <http://www.companydirectors.com.au/Director-Resource-Centre/Governance-andDirector-Issues/Board-Diversity/Statistics>. As at July 2014, these were the latest statistics available, which are updated on a quarterly basis.

${ }^{58}$ Broderick, above n 54.

59 Ibid.

${ }^{60}$ Forbes Insights, above n 34, 8.

${ }^{61}$ Deloitte, above n 34, 15.

62 Robin J Ely and David A Thomas, 'Cultural Diversity at Work: The Effects of Diversity Perspectives on Work Group Processes and Outcomes’ (2001) 46(2) Administrative Science
} 
the dominant paradigms for understanding diversity, focusing the lens on equal opportunity, fair treatment, fair recruitment, and compliance with legislation. ${ }^{63}$ The access and legitimacy paradigm reflects the need to accept and celebrate difference, matching the demographics of the corporation to those of the community. ${ }^{64}$ The learning and effectiveness paradigm links primary tasks to markets, products, strategies, missions, business practices and cultures, enriching decision-making in governance. ${ }^{65}$ Considering the fact that 50.2 per cent of Australia's population is female, ${ }^{66}$ but, on 28 May 2014, women accounted for only 18.2 per cent of directorships among Australia's top 200 listed companies, ${ }^{67}$ each of these arguments has some currency and they are convincing.

\section{What Is the Right Gender Balance?}

Evidence suggests that it is theoretically possible to achieve the 'right gender balance' on a corporate board. Those who present such evidence argue that the 'right gender balance' is denoted by a minimum 40 per cent representation of each sex, which can be achieved by either voluntary or mandatory means. ${ }^{68}$

Various reference points are relevant when considering optimum corporate board gender balance. Examples of relevant statistical benchmarks include: the percentage of women in the population, the percentage of women in the labour force, or the percentage of women on government boards (in aggregate and/or on each board - see Table 1 in the Appendix to this article for strategies that have been used on government boards). Alternatively, arbitrary percentages, which clearly indicate a move towards absolute equality, may also be argued to provide the 'right gender balance'. Thus, although one can speculate on what the 'right' gender balance is, it is impossible to determine

\footnotetext{
Quarterly 229; David A Thomas and Robin J Ely, 'Making Differences Matter: A New Paradigm for Managing Diversity’ (1996) 74(5) Harvard Business Review 79.

${ }^{63}$ Ely and Thomas, 'Cultural Diversity', above n 62, 245-6.

${ }^{64}$ Ibid 231, 243-4.

${ }^{65}$ Ibid $231 \mathrm{ff}$.

${ }^{66}$ Australian Bureau of Statistics (ABS), 3235.0 - Population by Age and Sex, Regions of Australia, 2011 (30 August 2013) <http://www.abs.gov.au/ausstats/abs@.nsf/Products/ 3235.0 2012 Main+Features Main+Features?OpenDocument>.

${ }^{67}$ AICD, above $n 57$.

${ }^{68}$ Armstrong and Walby, above n 5, 4.
} 
this with precision but the aspiration, worldwide, is to have between 30 and 50 per cent of a particular gender on boards of at least listed companies.

\section{QUOTA LEgISLATION}

The concept of quota legislation refers to legislated change that sets a target for the gender percentage on corporate boards to be achieved within a certain timeframe. Governments in several international jurisdictions have elected to phase in gender quotas over different timeframes, passing laws for this purpose; they have adopted variable approaches to sanctions and compliance requirements for companies of differing legal status. However, the approach of these governments has shown little variation concerning gender equality targets for quota legislation (nor has there been substantial variation among the targets of nations pursuing voluntary mechanisms). An international consensus has established that a minimum of 40 per cent of each gender holding directorships on a board represents best practice, as illustrated by some international jurisdictions (discussed below) which have adopted quotas.

\section{A Norway First out of the Blocks}

The first corporate board gender quota law in the world was introduced by Norway, through amendments to the Norwegian Public Limited Liability Companies Act. ${ }^{69}$ In February 2012, it remained 'the only example of fully implemented legislation (in the sense that the date for meeting the target has passed)'. ${ }^{70}$ Norway's model was successful due to the strictness of sanctions supporting its legislation. The ultimate sanction for a company not achieving the mandatory gender quotas is the dissolution or deregistering of the company. $^{71}$

\footnotetext{
${ }^{69}$ Aagoth Storvik and Mari Teigen, Women on Board: The Norwegian Experience (June 2010) Friedrich Ebert Stiftung, 3 <http://library.fes.de/pdf-files/id/ipa/07309.pdf >, cited in Armstrong and Walby, above n 5, 6. In 2003, Norway's Companies Act was amended, to include the gender quota requirements for company boards under, specifically, sub-s 6-11a: Norwegian Public Limited Liability Companies Act, translated by Schjødt to reflect all amendments up to 20 June $2014<$ http://www.oslobors.no/ob_eng/Oslo-Boers/ Regulations/Acts>.

${ }^{70}$ Armstrong and Walby, above n 5, 6.

${ }^{71}$ Ibid 6, 14, 31; Deloitte, above n 34, 21.
} 
The Norwegian legislation demanded that, for 'larger boards, $40 \%$ of the members were to be of each gender; a more detailed specification was made for smaller boards (if two or three members, then there should be one of each gender; if four or five members, at least two of each; if six-eight at least three of each; if nine or more then $40 \%){ }^{, 72}$ Companies had five years until January 2008 to implement targets.

There remains no room for non-compliance in Norway, and the sanctions ensured rapid results. ${ }^{73}$ Norway first mandated gender quotas for publicly listed companies by demanding a minimum of 40 per cent female directorship by $2008 .^{74}$ Public limited companies had until 1 January 2008 to meet the requirements and they were indeed met. Thus, although, as pointed out above, the final consequence for non-compliance was the dissolving of the company, no public limited company has been dissolved on account of the gender rules to date. ${ }^{75}$

Norwegian legislation demanded its companies increase female board representation from 7 per cent ${ }^{76}$ to 40 per cent in only five years - a 472 per cent increment on the base level. ${ }^{77}$ This required Norwegian companies to double their starting rate in the first year (2004) and then continue that same rate consistently for a period of five years (for example, 7 per cent in 2003, to 14 per cent in 2004, 21 per cent in 2005, 28 per cent in 2006, 35 per cent in 2007, and 40 per cent in 2008). Corporate board female representation rose from only 6 per cent in 2002 (prior to the passing of the quota law) 'to $9 \%$ in $2004,12 \%$ in $2005,18 \%$ in $2006,25 \%$ in $2007,36 \%$ in 2008 , reaching $40 \%$ in $2009{ }^{78}$ However, implementation took 10 years, 'from the first government motion until the final implementation of the quota', ${ }^{79}$ which was

\footnotetext{
${ }^{72}$ Armstrong and Walby, above n 5, 6, 14, 31.

${ }^{73}$ Jamie Atkinson, 'Gendered Organizations and Women's Career Progression in the Financial Services Sector' (2011) 33(3) Journal of Social Welfare and Family Law 243, 248, cited in Armstrong and Walby, above n 5, 10.

${ }^{74}$ See above $n$ 69. See also Armstrong and Walby, above n 5, 4.

${ }^{75}$ Deloitte, above n 34, 21.

${ }^{76}$ Arni Hole, Norwegian Ministry of Children, Equality and Social Inclusion, 'Diversity Deployed, the Norwegian Experiences' (Speech delivered to the second Diversity on Boards Forum, Sydney, 2-3 September 2009) 2.

${ }^{77}$ The 472 per cent increase [([40\%-7\%]/7\%)*100] required an effective doubling of Norway's female board representation year-on-year to achieve the quota requirements by 2008 .

${ }^{78}$ Storvik and Teigen, above n 69, 12.

${ }^{79}$ Ibid 5.
} 
considered too long by many and recommended to be avoided by nations seeking to emulate Norway. ${ }^{80}$

The fact that the 500 largest Norwegian company boards had averaged 7 per cent female representation in 2003 caused political embarrassment. ${ }^{81}$ Australia reported comparable statistics; ${ }^{82}$ yet a decade later Norway has almost three times the percentage of women on boards that Australia has: Australian boards have 13.8 per cent female directors, compared to 36.3 per cent in Norway (as at the end of 2011, reflected in figures released in March 2012). ${ }^{83}$

The achievement of the Norwegian objective encouraged other countries to implement similar quota legislation. ${ }^{84}$

\section{B Impact of Norwegian Legislation on Other Jurisdictions}

Norway's success inspired several nations to follow its lead. ${ }^{85}$ Countries that have implemented quota legislation ${ }^{86}$ include France, Belgium, Italy and

${ }^{80}$ Ibid 12.

${ }^{81}$ Hole, above n 76, 2.

${ }^{82}$ Ministry of Children, Equality and Social Inclusion, 'Representation of Both Sexes on Company Boards' in Broderick, above n 54.

${ }^{83}$ GMI Ratings, 'GMI Ratings' 2012 Women on Boards Report Shows Women Hold More than One in Ten Board Seats Globally' (Press Release, 8 March 2012) <http://www3.gmiratings.com/home/2012/03/gmi-ratings\%E2\%80\%99-2012-women-onboards-report-shows-women-hold-more-than-one-in-ten-board-seats-globally/>.

${ }^{84}$ Armstrong and Walby, above n 5, 30.

${ }^{85}$ Forbes Insights, above n 34, 27.

${ }^{86}$ Thirteen countries have recently enacted laws for the introduction of gender equity quotas for corporate boards, including: Austria, Belgium, Denmark, Finland, France, Iceland, Ireland, Israel, Italy, Norway, Spain, Switzerland, and the Netherlands: see Lord Davies, Women on Boards (Report, UK Government Department for Business, Innovation and Skills, 2011) $<$ https://www.gov.uk/government/uploads/system/uploads/attachment_data/file/31480/11745-women-on-boards.pdf $>$. See also European Commission's Network to Promote Women in Decision-Making in Politics and the Economy, 'The Quota-Instrument: Different Approaches Across Europe' (Working Paper, June 2011) <http://ec.europa.eu/justice/genderequality/files/quota-working_paper_en.pdf>; Rohini Pande and Deanna Ford, 'Gender Quotas and Female Leadership' (Background Paper, World Development Report on Gender, 7 April 2011) World Bank <http://siteresources.worldbank.org/INTWDR2012/Resources/ 7778105-1299699968583/7786210-1322671773271/Pande-Gender-Quotas-April-2011.pdf>; Mirella Visser, 'Advancing Gender Equality in Economic Decision-Making' (Background 
Spain, but the specific gender quotas and the sanctions if not achieved vary for all these countries. ${ }^{87}$ France passed a quota law in January $2011^{88}$ requiring that ' 40 per cent of executive board members of the largest publiclytraded companies (quoted on the stock exchange, or those with more than 500 employees, with a turnover exceeding $€ 50$ million over the previous three years)' be female, with a deadline of $2016 .^{89}$ French law has a transitional period with two phases (20 per cent by 2013 and 40 per cent by 2016) with penalties including 'annulment of board appointments'. .9

A Belgian quota law ${ }^{91}$ was implemented via a new article inserted into the Belgian Company Code, requiring a minimum of one-third female and onethird male directors on publicly traded and state-owned company boards, effective from 'the first fiscal year following the publication of the law'. ${ }^{92}$ The law was published on 14 September 2011 after being approved on 28 July 2011 and penalties for non-compliance include the '[t]emporary loss of financial and non-financial benefits by board members'. ${ }^{93}$

\footnotetext{
Note presented at European Conference on Equality between Women and Men, Brussels, 1920 September 2011) < http://ec.europa.eu/justice/gender-equality/files/conference_sept_2011/ background-paper-decision-making_en.pdf $>$; Armstrong and Walby, above n 5, 6 .

${ }^{87}$ See also Armstrong and Walby, above n 5, 30-1.

${ }^{88}$ Timothy Hindle, 'Help Wanted: Women for Europe’s Boards' (2011) Briefings on Talent and Leadership Magazine in Deloitte, above n 34, 15.

${ }^{89}$ Ibid.

${ }^{90}$ Armstrong and Walby, above n 5, 30.

91 'The Belgian law of 28 July 2011 on the reform of certain government-held companies, the Belgian Company Code and the National Lottery, aims to guarantee a representation of women on the boards of autonomous government-held companies, publicly-listed companies, and the National Lottery': Myriam Van Varenbergh, 'Women in Economic Decision Making' (Comments Paper, Exchange of Good Practices on Gender Equality, European Commission (Justice), 10-11 May 2012) 2 <http://ec.europa.eu/justice/gender-equality/files/exchange _of_good_practice_no/be_comments_paper_no_2012_en.pdf $>$.

${ }^{92}$ Deloitte, above n 34, 16. A new article was inserted into the Belgian Companies Code via art 518 bis. The quota requires that, for public and state-owned companies, at least one-third of directors 'should be of a different gender to the other members of the board of directors': Mathilde van der Stegen, Towards a Feminization of the Board of Directors: The Introduction of a Gender Quota for Belgian State-Owned and Publicly-Traded Companies (27 March 2013) Association of Corporate Counsel <http://www.lexology.com/library/ detail.aspx?g=67a644f5-6bba-4033-a24d-62774df63e30>.

${ }^{93}$ Armstrong and Walby, above n 5, 30.
} 
On 28 June 2011, Italy implemented quota Law no 120/2011. ${ }^{94}$ The changes were implemented in July-August 2011. ${ }^{95}$ The law requires that the lowest represented gender on the Boards of Directors and Audit Committees should originally be increased to one-fifth for the first three years after the provisions became law and to at least one-third after that three-year period. Italy's Gender Parity Law applies to 'public limited companies and state-owned companies' and demands 'at least 33\% of each gender on their boards (executives and non-executives) by 2015 (with a target of 20\% for the transitional period) ${ }^{96}$ The consequences of non-compliance are severe: companies will receive a warning, with four months grace to rectify the matter. If they fail to achieve quotas the company is fined between $€ 100000$ and $€ 1$ million and its audit committee is fined between $€ 20000$ and $€ 100000$, with a further three months to rectify the situation. ${ }^{97}$ Continued failure to comply results in removal of the board and audit committee. ${ }^{98}$

Spain introduced its gender quota law in 2007 by passing the Constitutional Act 3/2007 of 22 March for Effective Equality between Women and Men, referred to as the 'Equality Law' (or La Ley de Igualdad). ${ }^{99}$ According to Article 75 of the Equality Law, '[c]ompanies obliged to present unabridged financial statements of income will endeavor to include a sufficient number of women on their boards of directors to reach a balanced presence of women and men within eight years of the entry into effect of this act'. The law defines 'a balanced presence' as a minimum of 40 percent of each gender and not exceeding 60 per cent of any gender. This provides further support for the

\footnotetext{
94 'On June 28, 2011 the Italian Parliament approved Law no 120/2011, a legislative enactment introducing affirmative action for women (significantly called, in Italian, "quote rosa", ie, "pink quotas") in companies:' Palomar-Osservatorio di dirrito constituzionale, The Italian Parliament Approves a Law Introducing an Affirmative Action to Promote Women's Representation in Companies (Law no 120/2011) (October 2011) $<$ http://www3.unisi.it/dipec/palomar/italy016_2011.html>.

${ }^{95}$ Deloitte, above n 34, 19.

${ }^{96}$ European Commission, 'National Factsheet: Gender Balance in Boards' (January 2013) 1 $<$ http://ec.europa.eu/justice/gender-equality/files/womenonboards/womenonboards-factsheetit_en.pdf>.

${ }^{97}$ Deloitte, above n 34, 19.

${ }^{98}$ Ibid. See also European Commission, above n 96, 1.

${ }^{99}$ Constitutional Act 3/2007 of 22 March for Effective Equality between Women and Men (22 March 2007) Coordinadora Española Para el Lobby Europeo de Mujeres ('Equality Law') $<$ http://www.celem.org/pdfs/Ley_Igualdad_Ing.pdf $>$. See further Nuria Chinchilla and Victoria Kraunsoe, Progressive Law in Spain Not Enough (5 September 2013) 20 First $<$ http://www.20-first.com/737-0-spanish-quota-does-not-take-hold.html>.
} 
general, international consensus of the right gender balance. ${ }^{100}$ Companies have until 2015 to comply. ${ }^{101}$ Spanish quota law differs from most others in that no penalties apply for non-compliance. The government has disclosed, however, that it will 'take compliance into consideration in the awarding of certain public contracts'. ${ }^{102}$ It will be interesting to track the statistical progress of board gender-diversity in Spain based on this incentive and in the absence of legal sanctions.

The Malaysian government, in 2004, published strong recommendations for the appointment of a minimum 30 per cent women at 'decision-making levels' for its public and corporate sectors. ${ }^{103}$ Following a slow response in the corporate sector, Malaysia announced a Cabinet-approved gender equity quota on 27 June 2011 and gave companies five years to comply. ${ }^{104}$ The Prime Minister stated that ' $[\mathrm{t}$ ]his decision reflects that the government today is not only supportive towards women's roles and success, but is also encouraging them to further move ahead in their career' ${ }^{105}$ Furthermore, to ensure the success of the quota, the Malaysian Finance Ministry, the Malaysian Alliance of Corporate Directors, and the Malaysian Directors Academy 'formulate training programmes to prepare those with potential for the board of directors' job'. ${ }^{106}$

It should be noted that although it has been widely reported that Malaysia has legislated a quota system, it remains a recommendation only and forms part of the revised Code of Corporate Governance, which took effect in 2012. ${ }^{107}$ Without the backing of legal enforcement, the recommendations have achieved only mixed results. ${ }^{108}$

\footnotetext{
${ }^{100}$ Susan Vinnicombe, Women on Corporate Boards of Directors: International Research and Practice (Edward Elgar Publishing, 2008) 101.

${ }^{101}$ Deloitte, above n 34, 22.

${ }^{102}$ Ibid.

${ }^{103}$ S Abdullah, Ku Nor Izah Ku Ismail and Lilach Nachum, 'Women on Boards of Malaysian Firms: Impact on Market and Accounting Performance' (10 September 2012) Social Science Research Network, $8<$ http://papers.ssrn.com/sol3/papers.cfm?abstract_id=2145007>.

${ }^{104}$ Deloitte, above n 34, 11.

${ }^{105}$ Mazwin Nik Anis, 'PM: 30\% of Corporate Decision-Makers Must be Women', The Star Online (online), 27 June $2011<$ http://thestar.com.my/news/story.asp?file=/2011/6/27/nation /20110627131533\&sec=nation>.

${ }^{106}$ Ibid.

${ }^{107}$ Abdullah, Ismail and Nachum, above n 103.

${ }^{108}$ Ibid.
} 
Over the next decade, inadequacies with voluntary mechanisms may lead other nations to follow suit and implement legislated quotas. ${ }^{109}$ Nations electing to pass quota legislation which differs from the strict sanction-based system of Norway may experience a fluctuation in board gender diversity statistics ${ }^{110}$ because of the scope given for non-compliance.

\section{Evaluating Mandatory Quotas to Achieve Gender Diversity}

\section{$1 \quad$ Advantages}

Advocates of legislation, in espousing the virtues of quotas, cite research correlating board-level gender diversity and corporate performance. The gender gap has been described as 'both an injustice and a drag on company economic performance'. ${ }^{111}$ Quotas have been proven to remedy the issue quickly, with Norway one of the countries providing evidence of this. ${ }^{112}$ Goldman Sachs posited that increasing female participation rates would lift Australian GDP by 11 per cent; ${ }^{113}$ if female productivity and participation were both raised to levels equivalent to those of males, GDP would increase by 20 per cent ${ }^{114}$ Based on this, quota legislation should be considered as an option to ensure that the economic advantage of having more females on boards could be reaped sooner than what would be the case if voluntary targets are achieved through a self-regulatory corporate governance model. To mandate minimum levels of female directorship would cast the net wider than is currently the case, leading to better use of talent and an increase in female productivity and participation. Quotas would remedy the current inequity and injustice of gender imbalance - in principle. If the research correlating gender diversity with corporate performance is relied upon, then the advantages of a legislated quota system in Australia could be substantial. The

\footnotetext{
${ }^{109}$ Forbes Insights, above n 34, 4, 27.

110 Ibid 4.

${ }^{111}$ Armstrong and Walby, above n 5, 5.

112 Ibid.

${ }^{113}$ Broderick, above n 54. See further Goldman Sachs, Australia's Hidden Resource: The Economic Case for Increasing Female Participation (26 November 2009) $<$ http://www.asx.com.au/documents/about/gsjbw_economic_case_for_increasing_female_par ticipation.pdf $>$, cited in Deloitte, above n 34, 2.

${ }^{114}$ Broderick, above n 54.
} 
promotion of board gender equity would further economic equality between the sexes. According to Forbes in its 2012 Global Diversity Rankings study:

It's worth noting that greater economic equality between men and women has been shown to reduce poverty rates, boost GDP and lead to better governance. In order to improve female participation rates, governments can adopt a number of proven approaches such as flexi-time initiatives, free or subsidized childcare, and tax breaks for married couples when both partners work. ${ }^{115}$

Quotas arguably circumvent the compounded effect of the stereotypes that men 'listen to men', ${ }^{116}$ mentor younger males by preference, ${ }^{117}$ and 'promote people like themselves'.118

\section{Disadvantages}

Several commentators believe that quotas forced Norwegian companies to 'window-dress' board appointments in order to meet strict legislation, ${ }^{119}$ devaluing female directorships by removing the opportunity for women to be promoted without doubt being cast on their merit. ${ }^{120}$

Whilst Norway achieved 40 per cent female directorship by 2009, at the same time a survey of the 'largest Norwegian companies' revealed that 'less than 1 per cent of the CEOs [were] women, while the average presence of women in the corporate management groups in these companies [was] 10 per cent'. ${ }^{12}$

\footnotetext{
${ }^{115}$ Forbes Insights, above n 34, 8.

116 Domini Stuart, Feature: The Gender Imbalance (1 June 2010) AICD $<$ http://www.companydirectors.com.au/Director-Resource-Centre/Publications/CompanyDirector-magazine/2010-back-editions/June-2010/June/Feature-The-gender-imbalance>.

117 The Economist, 'Women in the Boardroom: The Wrong Way to Promote Women' (21 July 2011) <http://www.economist.com/node/18988506>.

${ }^{118}$ Ibid.

119 The Economist, 'Women in Business: Still Lonely at the Top' (21 July 2011) $<$ http://www.economist.com/node/18988694>.

${ }^{120}$ Gael O'Brien, Women in the Boardroom: Should the US Have Quotas? (3 August 2011) Business Ethics <http://business-ethics.com/2011/08/03/women-in-the-boardroon-should-theus-have-quotas/>.

${ }^{121}$ Vibeke Heidenreich, ‘Kjønn og makt i norsk næringsliv’ in K Niskanen and A Nyberg (eds), (2009) 59 Kön og makt i Norden, del I, Landsrapporter TemaNord, cited in Mari Teigen, Exchange of Good Practices on Gender Equality (May 2012) European Commission (Justice), $10<$ http://ec.europa.eu/justice/gender-equality/files/exchange_of_good_practice_ no/no_discussion_paper_no_2012_en.pdf>.
} 
Chairpersonship remains male-dominated ${ }^{122}$ and a recent study of 'prime insiders' on the Oslo stock exchange - completed by Burson-Marsteller indicates that women account for only $27 \%$ of a wider group of prime insiders and only $8 \%$ of 'the most trusted' prime insiders within Norway's top companies. ${ }^{123}$ Based upon 2010 data - one year after achieving the mandated 40 per cent female directorship target - companies on the Oslo Stock Exchange had female CEO representation of only 2 per cent. ${ }^{124}$ Such statistics bring into question the depth of commitment to gender diversity in countries with mandated quota law.

Many companies and commentators oppose legislated gender quotas as they force the appointment of individuals without the necessary qualifications, experience and preparedness, rather than appointments being made on merit. ${ }^{125}$ Such appointments are considered a threat to corporate governance structures and performance. Significant research, adjusted for reversecausation, indicates that gender diversity negatively affects corporate performance. ${ }^{126}$ As will be seen below, some also believe that the market should judge corporate governance practices; legislation dilutes the effect of that prerogative.

\section{Voluntary Regime in Australia}

Unlike a quota system, a voluntary regime allows corporations and their boards to set their own targets for gender diversity on corporate boards, as

\footnotetext{
${ }^{122}$ Storvik and Teigen, above n 69, 3.

123 'Most trusted' positions were indicated by Burson-Marsteller as 'Chairmen, CEOs and CFOs’: Burson Marsteller, InnsideBorsen Q1 2012 (22 January 2012) 2 <http://bursonmarsteller.no/wp-content/uploads/2012/01/InnsideBørsen-Q1-2012.pdf>, cited in Teigen, above n 121, 10. Inaki Longarela and Lene Foss, The Norwegian Paradox: A Literature Review (University Business School, University of Tromsø, 2011) 3.

${ }^{124}$ Storvik and Teigen, above $\mathrm{n}$ 69, 3.

${ }^{125}$ Rapidly increasing the rate of female appointments requires a substantial increase in firsttime directorships, which arguably may cause a risk to the corporate governance of companies. In 2010, 55 per cent of female director appointments to ASX 200 boards were first-time ASX 200 directors; see Broderick, above n 54. The merit principle 'aims to ensure that leadership selection processes are fair, impartial and transparent. It means the outcome isn't based on where you went to university, or who you know, or what your parents do. The merit principle is intended to eliminate favouritism, nepotism and bias - and ... sexism': C Burton, 'Merit, Gender and Corporate Governance' in Linda Hancock (ed), Women, Public Policy and the State (Macmillan Education, 1999), cited in Broderick, above n 54.

${ }^{126}$ See above Part III.
} 
long as reasons are provided for non-compliance with the national guidelines introduced by the ASX in 2003. This can be done in companies' own timeframes, with minimal government interference, enabling corporate boards to retain discretion in directorship recruitment, and avoid compliance costs and penalties whilst committing to a culture of gender equity by choice.

The approach taken in Australia is set against the background of the diversity debate discussed above. Within the broader societal context of equality and participation, some have observed that the increase in the appointment of women to corporate boards has occurred slowly, starting at the beginning of the women's movement in 1970 and being promoted by changes in the social, economic, political, and competitive environments (see Table 1 in the Appendix). The table illustrates that change occurred in two contexts (defined as the outer context of the social, economic, political and competitive environments and the inner context entailing the structure, corporate culture and political environment within the community). The table shows that the development of board diversity is not a simple linear process, but that actions, reactions and interactions of stakeholders occur in an interlocking manner over time. It is a combination of events at a variety of levels interacting over time as the change process is given legitimacy by people in power on boards who respond to the idea of mentoring and developing mentor and develop women for board positions.

Table 1 illustrates how the development of board diversity has occurred in three phases. Phase 1 focused on equal rights for women and girls, with little movement of women onto boards. Phase 1 was revolutionary and radical, with high levels of activity on the streets, in the media, and through publications such as books and journal articles. Phases 2 and 3 were evolutionary. Phase 2 focused on positive actions for women in the workplace, with an emphasis on management rather than governance, but with some women obtaining board positions. The focus was on 'education and equality' for women and girls equal opportunities for women in society, such as the removal of explicit barriers to the admission and progression of women in the workforce. Phase 3 focused on women seeking power and influence through diversity mainstreaming and through gender access to the boardroom. Each of these periods of change was associated with the election of federal Labor governments. 


\section{A The 2009 CAMAC Diversity on Boards of Directors Report}

During the financial year 2009/2010, the Australian government commissioned three independent reviews seeking recommendations on listedentity corporate governance practices, with an emphasis on gender diversity. ${ }^{127}$ The commissioned reports were:

- $\quad$ The CAMAC Report, Aspects of Market Integrity, June 2009;

- $\quad$ The CAMAC Report, Diversity on Boards of Directors, August 2009; and

- The Productivity Commission Inquiry Report, Executive Remuneration in Australia, January 2010.

With some studies identifying a causal link between board diversity and better corporate performance, CAMAC ${ }^{128}$ investigated board diversity in 2009. The CAMAC Report in turn contributed to the ASX Corporate Governance Council's construction of the Corporate Governance Principles and Recommendations with 2010 Amendments which will be discussed further below. On 9 September 2008, Senator Nick Sherry (Minister for Superannuation and Corporate Law) directed CAMAC to investigate and advise upon board diversity at the March 2009 meeting of the Ministerial Council for Corporations. ${ }^{129}$ The completed report, including recommendations, was entitled Diversity on Boards of Directors Report, and was delivered to the Minister on 2 March 2009. ${ }^{130}$

\footnotetext{
${ }^{127}$ ASX Corporate Governance Council, 'Amendments to the Corporate Governance Principles and Recommendations 2nd Edition' (Response Paper to Submissions, 30 June 2010) ('Governance Principles') 3 <http://203.170.82.73/ firstgro/wordpress/wp-content/uploads/ 2010/07/cg_response_paper_june_2010.pdf $>$.

${ }^{128}$ CAMAC, above n $34,1$.

${ }^{129}$ Ibid.

${ }^{130}$ Ibid.
} 


\section{B Gender Diversity on Australian Boards Compared to Other Countries}

Indeed, Australian women represent 45.8 per cent of the total labour force, ${ }^{131}$ placing $23^{\text {rd }}$ among 50 participating nations in Forbes' 2012 'female employment share rank'. ${ }^{132}$ The 2011 Australian sex ratio (the number of males per hundred females) was 98.9 across a total population of 22.3 million, meaning that women comprise 51 per cent of the Australian population. ${ }^{133}$ However, as pointed out above, at 28 May 2014, only 18.2 per cent of ASX 200 directorships were held by females. ${ }^{134}$ The proportion of women on boards in Australia compared to Norway remains low, evidenced by Australia's ranking of 21 among 50 participating countries in Forbes' 2012 Global Diversity Ranking. ${ }^{135}$ Forbes commissioned Oxford Economics to build a global ranking model, which was 'unique and first-of-its-kind'. ${ }^{136}$ Australia's middle of the field female directorship ranking is unfortunate considering that several participating countries have insular approach[es] to boardroom diversity'. ${ }^{137}$ Japan and the United Arab Emirates (placed $49^{\text {th }}$ and $48^{\text {th }}$ ), for example, recorded female corporate board representation of only 0.9 per cent ${ }^{138}$ within strong cultures that traditionally favour male-dominated leadership and governance.

In Forbes' female directorship ranking, Australia placed behind New Zealand $\left(13^{\text {th }}\right)$ and the US $\left(14^{\text {th }}\right)$ but ahead of the United Kingdom (UK) $\left(28^{\text {th }}\right)$ among nations with which it has close cultural ties. ${ }^{139}$ The five best performing nations were Norway (36 per cent), the Philippines (23 per cent) and Sweden

\footnotetext{
${ }^{131}$ ABS, Cat 6202.0 - Labour Force, Australia, Status by Sex-Trend March 2012 (12 April 2012) in Australian Government Equal Opportunity for Women in the Workplace Agency, Gender Workplace Statistics at a Glance (October 2013) <http://www.wgea.gov.au/sites/ default/files/2013-10-10-Stats-at-a-Glance_0.pdf > .

${ }^{132}$ Forbes Insights, above n 34, 10.

${ }^{133}$ ABS, above $n 66$.

${ }^{134}$ AICD, above n 57.

${ }^{135}$ Forbes Insights, above n 34, 4.

${ }^{136}$ Ibid. The model assessed and compared employee and board diversity 'across 50 global economies, 14 industrial sectors and nine occupations'. Forbes' research data was collected by Oxford Economics 'in early 2011 and in most cases represents the years 2008, 2009 or 2010'.

${ }^{137}$ Ibid 8, 10-11.

${ }^{138}$ Ibid.

${ }^{139}$ Ibid.
} 
(23 per cent), Latvia (22 per cent) and Slovakia (22 per cent). ${ }^{140}$ The five worst performing nations were Portugal ( 0.4 per cent), Japan ( 0.9 per cent), the United Arab Emirates ( 0.9 per cent), Korea (1 per cent) and Chile (2.4 per cent). ${ }^{141}$ Forbes' study is comprehensive and unique, providing a detailed, comparative analysis of gender diversity around the world; however, data was collected in early 2011 and represents 2008, 2009 or 2010 - meaning that Australia's rapid progress since 2010 is not exhibited in the Forbes results. A less comprehensive but more current study performed by GMI and based upon December 2011 data was released on 8 March 2012 to coincide with International Women's Day. ${ }^{142}$ GMI's study revealed that Australia's rate of increase in female directorships during 2011 had elevated it above several nations behind which it had previously lagged. ${ }^{143}$ In Part VII below, the authors analyse statistics regarding male and female percentages of directorships for ASX 200 companies in greater detail.

\section{Australia's Weighted Composite Gender Diversity Ranking}

Whilst Australian board-level gender diversity remains well short of international benchmarks, Australia's weighted composite gender diversity ranking is more impressive $\left(12^{\text {th }}\right) .{ }^{144}$ In order to reach the composite gender diversity rank, four measurable elements of gender diversity were considered and results were weighted to determine the relevant placing for each of the 50 participating countries. The four elements were: female employment share rank (for which Australia placed $\left.23^{\text {rd }}\right)$, female activity rate rank $\left(12^{\text {th }}\right)$, women on boards rank $\left(21^{\text {st }}\right)$, and women in Parliament rank $\left(17^{\text {th }}\right)$. Australia's composite weighted result was 0.63 , placing it $12^{\text {th }} .{ }^{145}$ By comparison, the first placed nation, Norway, achieved an overall weighted score of 0.90 , placing fifth, third, first and eighth in each of the four respective measures identified above.

\footnotetext{
140 Ibid 9.

${ }^{141}$ Ibid 9.

142 Kimberly Gladham and Michelle Lamb, GMI Ratings' 2012 Women on Boards Survey (March 2012) GMI Ratings, 1 <http://library.constantcontact.com/download/get/file/ 1102561686275-86/GMIRatings_WOB_032012.pdf >.

143 Ibid 8.

${ }^{144}$ Forbes Insights, above n 34, 10.

${ }^{145}$ Ibid.
} 
The composite gender diversity rank may be interpreted as a leading indicator of board gender diversity performance. Its strong performance in the four elements studied suggests that Australia is improving opportunities for minority groups and enhancing diversity in all levels of the economy and corporate life. $^{146}$

\section{Cultural Change a Driving Force for Diversity}

A change in cultural attitudes, so that the advantages of diversity are recognised and female participation encouraged, will increase the quantity of qualified, experienced female directors in a sustainable and productive manner. Current data demonstrates improvement in Australia's board-level gender diversity, with 22 per cent of all new 2012 ASX 200 board appointments being women (or a total of 41 women). ${ }^{147}$ Strong progression towards equitable representation has continued over three years, with 68 female appointments in 2011 (comprising 28 per cent of the total) and 56 (comprising 25 per cent of new appointments) in $2010 .^{148}$

\section{E The ASX Corporate Governance Council's Corporate Governance Principles and Recommendations}

The document entitled Corporate Governance Principles and Recommendations with 2010 Amendments was adopted by the ASX Corporate Governance Council, following public consultation. The document came into effect from the first financial year commencing on or after 1 January 2011 149 and, within established principles, addressed diversity-related issues. Principle 2 in the document deals with the issue of structuring the board to add value. Specifically, Principle 2.4 ('The board should establish a nomination committee') ${ }^{150}$ requires boards to report upon director recruitment, including

\footnotetext{
${ }^{146}$ No director should be appointed to any board based solely upon the diversity group they represent: O’Brien, above $n$ 120. In order for the talent pool to be fully utilised, opportunities for all individuals - particularly those from under-represented minority groups — to become sufficiently qualified and prepared for directorship is essential.

${ }^{147}$ AICD, above $\mathrm{n} 57$.

${ }^{148}$ Ibid.

${ }^{149}$ ASX Corporate Governance Council, Governance Principles, above n 127, 7.

150 ASX Corporate Governance Council, Corporate Governance Principles and Recommendations Summary of 30 June 2010 Amendments (30 June 2010)
} 
procedures to consider talent from diverse sources. In its 2009 report, CAMAC had recommended that 'a starting point in any move to encourage greater gender (or other) diversity on boards is to ... make their appointment processes more transparent and to formalise their processes for keeping board composition under review in the light of performance and changing needs'. ${ }^{151}$ No change to the principle was made; however, additions were recommended under 'Selection and appointment process and re-election of directors', with the aim of promoting diversity by encouraging companies to consider broad sources when recruiting directors. ${ }^{152}$

Principle 2.5 ('Companies should disclose the process for evaluating the performance of the board, its committees and individual directors') provides additional commentary regarding director 'induction and education', company culture and values, and director interactions with senior management. ${ }^{153} \mathrm{~A}$ risk of continuing to increase female directorships rapidly is that a possible shortage of qualified candidates with directorship experience or preparation may arise. On 1 January 2010, Australian ASX 200 company boards had only 8.3 per cent female directorship representation. ${ }^{154}$ Indeed, '55\% of the new female appointments made in 2010 were women who had not previously sat on an ASX 200 board' and as female representation continues to increase, this figure is likely to remain high. ${ }^{155} \mathrm{~A}$ fundamental aim of this principle is to support the transition of inexperienced directors into the governance structure, to improve their likelihood of performing well and, hence, to reinforce the corporation's decision to recruit diverse talent. The Australian voluntary regime aims to improve gender equality at board level, whilst ensuring optimal corporate performance. ${ }^{156}$ Encouraging a rapid, substantial and continuous increase in this rate necessarily requires a substantial increase in the number of first-time female directors. Induction is imperative to support this process. The potential lack of cohesion of diverse boards has been noted as interfering with problem-solving efficacy. Detailing meeting arrangements

\footnotetext{
('Recommendations Summary') <http://www.asx.com.au/documents/asx-compliance/cg comparative_table_june_2010.pdf > 1-2.

${ }^{151}$ CAMAC, above n 34, 52-3.

152 ASX Corporate Governance Council, Recommendations Summary, above n 150, 1-2.

153 Ibid 2.

${ }^{154}$ AICD, above $n 57$.

${ }^{155}$ Broderick, above n 54 .

${ }^{156}$ Ibid.
} 
as well as 'director interaction[s] with each other, senior executives and other stakeholders' helps the cohesiveness of a diverse board. ${ }^{157}$

Principle 3 promotes ethical and responsible decision-making, with Principle 3.2 representing the most significant amendment to the ASX's Corporate Governance Principles and Recommendations. It requires the establishment of a diversity policy, the implementation of measurable objectives and the adoption of annual monitoring. ${ }^{158}$ To assist corporations in their adoption of the amended recommendations, Principle 3.2 provides a definition of diversity, stating that it 'includes but is not limited to gender, age, ethnicity and cultural background'. ${ }^{159}$ Measurable objectives are recommended to 'identify how you measure achievement of gender diversity objectives, for example, proportion of women in the company, senior executive positions and on the board'. ${ }^{160}$ Supported by a diversity policy and annual monitoring, corporations that adopt the amended Principle 3.2 will be able to measure progress towards diversity targets (objectives). The implementation of measurable objectives allows variances to be identified, discussed and explained. Many subscribe to the adage that 'what gets measured gets done' and the strength of this amendment is that, whilst compliance is voluntary, it possesses a measurable element, which demands the attention of key senior personnel in Australian corporations. The progress of Australian companies towards their own pre-determined, measurable diversity objectives must be tabled, monitored and discussed periodically; in that way, diversity becomes a significant issue within the corporation. Feedback from public consultation, with which the ASX's Corporate Governance Council agreed, noted the inflexibility with which companies quantified measurable objectives in diversity policy. ${ }^{161}$

Principle $3.3^{162}$ requires the disclosure by companies of measurable objectives and annual progress. Accompanying commentary highlights the need for a governance culture which is supportive of diversity and female participation. ${ }^{163}$ Specifically, '[c]ompanies should disclose in each annual

${ }^{157}$ ASX Corporate Governance Council, Recommendations Summary, above n 150, 2.

${ }^{158}$ Ibid 3.

159 Ibid.

${ }^{160}$ Ibid.

${ }^{161}$ ASX Corporate Governance Council, Governance Principles, above n 127, 6.

${ }^{162}$ ASX Corporate Governance Council, Recommendations Summary, above n 150, 5.

163 'The role of shareholders is enhanced if they are fully informed of the policy and measurable objectives which facilitate tracking and monitoring against the objectives': ibid 5 . 
report the measurable objectives for achieving gender diversity set by the board in accordance with the diversity policy and progress towards achieving them'. ${ }^{164}$

Principle 3.4 requires disclosure in annual reports of the numbers of female employees, senior executives and directors. ${ }^{165}$ Additional commentary on the Principle suggests that the remuneration committee/board should, at least annually, review and report upon gender balance at all company levels.

Principle 8 promotes fair and responsible ${ }^{166}$ remuneration, with Principle 8.1 requiring that the board should establish a remuneration committee, and expecting the board or remuneration committee to consider remuneration by gender as well as making some comments on gender-based remuneration.

The ASX's Corporate Governance Principles and Recommendations are developed on an 'if not, why not' basis, ${ }^{167}$ enabling listed companies to elect not to adopt any recommendation, provided they disclose reasons why it was not adopted. Since their introduction during 2003, the principles and recommendations have been voluntary. However, the cooperative premise of the document and its value as a tool to analyse the corporate governance performance of Australian companies has ensured that it was adopted by almost all listed companies. ${ }^{168}$ The Australian framework supports the principle that it is ultimately 'for the market to pass judgement on the corporate governance practices of Australian companies, ${ }^{169}$ and it is hoped that the 'cooperative goodwill of listed entities' will continue with regard to board gender diversity, avoiding the need for legislative intervention. ${ }^{170}$

\footnotetext{
${ }^{164}$ Ibid.

${ }^{165}$ Ibid 5-6.

${ }^{166}$ Ibid 7-8.

${ }^{167}$ ASX Corporate Governance Council, Recommendations Summary, above n 150, 2, 6.

${ }^{168}$ ASX Corporate Governance Council, Governance Principles, above n 127, 2.

169 ' ... not the Council or ASX': ibid.

${ }^{170}$ The '[c] $]$ ooperative goodwill of listed entities has contributed to a high standard of corporate governance practice in Australia without the agency costs of "black letter" law common in other markets': ibid.
} 


\section{F Employee Diversity in Australia}

Australia was placed fourth out of 50 nations in Forbes' 2012 'global index of employee diversity', ${ }^{171}$ a study analysing various diversity elements, including gender, age, country of birth, part-time or full-time employment, education, income and sector. ${ }^{172}$ New Zealand, one of Australia's nearest neighbours in both proximity and cultural values, ${ }^{173}$ ranked second. ${ }^{174}$ The result is encouraging for workplace diversity and the provision of equal opportunities for employees. The Forbes' study was limited, however, by inconsistent availability of statistical data for key diversity elements in participating nations. For example, the US and UK are the only two countries tracking employment data on ethnicity. ${ }^{175}$ However, considering the elements of diversity studied and their comparative results, Australia rates in the upper echelon of nations providing equal opportunities to all employees, established by the fact of employee diversity.

\section{G Long-Term Flow-On Effects of Employee Diversity on Board Diversity}

As a leading indicator, the composite index of employee diversity bodes well for long-term Australian board diversity. By committing to diversity at the employee level, across all sectors of the economy and with consideration of all diversity elements, Australia is creating a culture of openness and acceptance of human differences. Acceptance should reduce bias, enhance employee diversity and provide opportunities for skills development, hence ensuring that individuals from diverse groups are better prepared to assume leadership and directorship positions in the future.

Investment and commitment at employee and management levels will prepare individuals from diverse representative groups for directorship positions via a 'push' strategy. Such an approach requires a long-term perspective but, in conjunction with adequate board training and appropriate measures that

\footnotetext{
${ }^{171}$ Forbes Insights, above n 34, 14-15.

${ }^{172}$ Ibid 12-15.

${ }^{173}$ Regional Language Network, Australia and New Zealand - People and Culture: A Guide for Business (16 July 2007) Hampshire Chamber of Commerce <http://www.hampshire chamber.co.uk/docs/Australia\%20and\%20New\%20Zealand.pdf >; The Free Dictionary, Antipodean <http://www.thefreedictionary.com/Antipodeans>.

${ }^{174}$ Forbes Insights, above n 34, 14.

${ }^{175}$ Ibid 18.
} 
encourage corporations to pursue diversity, it may achieve balanced corporate governance results in the long term.

Despite there being a significant difference between managing and directing a corporation, ${ }^{176}$ directorship is commonly preceded by senior-executive experience. ${ }^{177}$ Only 24 per cent of Australian senior managers are women; ${ }^{178}$ however, Australia has the greatest proportion of female CEOs (30 per cent) of any country - an enviable result and a leading indicator for future Australian board-level gender diversity. ${ }^{179}$ The promotion of diversity at all corporation levels and across each segment of the economy provides Australia with an opportunity to nurture qualified board talent from currently underrepresented minority groups.

\section{H Australia's Voluntary Regime: To Force or Not to Force?}

In April 2011, Elizabeth Broderick, Sex Discrimination Commissioner and the then Age Discrimination Commissioner of the Australian Human Rights Commission, noted that 'most organisations had interpreted "measurable objectives" [in Principle 3.2 of the ASX Corporate Governance Council, Corporate Governance Principles and Recommendations] as targets'. ${ }^{180}$ In a speech to the third Women on Boards Conference, 'Gender Matters',

\footnotetext{
${ }^{176}$ See sources in Jean Jacques du Plessis, Anil Hargovan and Mirko Bagaric, Principles of Contemporary Corporate Governance (Cambridge University Press, 2011) 78-9.

177 John Cloney, Chairman of QBE, notes that '[q]uite simply, there are fewer women in the pool', with regard to directorship selection. 'Right or wrong, a lot of companies look for directors with CEO experience and that instantly knocks out a large percentage of female candidates. If you then say you want a director with CEO experience in a publicly-listed company, that knocks out another big percentage', in Stuart, above n 116.

178 Compared to the global average of 21 per cent: Grant Thornton, Women in Senior Management: Still Not Enough (8 March 2012) 5 <http://www.grantthornton.co.nz/Assets/ documents/pubSeminars/IBR-2012-women-in-senior-management.pdf $>$. However, this data shows substantial improvement on the 2010 rate for female listed-company senior executives, which was only 10.7 per cent: Stuart, above n 116 .

179 Grant Thornton, above n 178, 8. However, recent research performed by the Australian Council of Super Investors (ACSI) revealed that, among the ASX 200, females account for only 4 per cent (8) of total CEOs and 4 per cent (8) of board chairs: Rachel Alembakis, ACSI Criticises Slow Pace of Women Appointed to ASX Boards (8 March 2013) The Sustainability Report <http://www.thesustainabilityreport.com.au/acsi-criticises-slow-pace-of-womenappointed-to-asx-boards/3439/>.

${ }^{180}$ Broderick, above n 34.
} 
Broderick re-stated the Australian Human Rights Commission's recommendation, contained in the 2010 Gender Equality Blueprint, ${ }^{181}$ that all publicly listed companies set minimum board representation targets of 40 per cent by gender, to be achieved by $2015 .{ }^{182}$

The Australian Human Rights Commission had made 15 recommendations in its 2010 Blueprint, all aimed at promoting gender diversity and equality. ${ }^{183}$ Recommendation 7, 'Promoting women in Leadership', had specified that 'a target of $40 \%$ representation of each gender on all publicly-listed Boards in Australia, to be achieved over five years, should be promoted' ${ }^{184}$ It had further been recommended that '[i]f progress is not made, the Australian Government should consider legislating to require publicly-listed companies and other large employers to achieve a mandatory gender diversity quota of a minimum of $40 \%$ of both genders within a specified timeframe [five years], failing which penalties will be imposed'. ${ }^{185}$

Whilst the target is ambitious, it is comparable with targets set in other countries $^{186}$ and must be pursued if Australia is to prove that voluntary regimes are a viable alternative to legislation. There are several reasons why it is important that Australia achieve the target.

First, the Australian Human Rights Commission is a respected organisation and its recommendations are considered credible. Second, the recommendation provides a quantitative target against which Australian company performance may be measured for critical analysis and to ensure progress towards a goal. Third, the recommended gender target of 40 per cent is comparable with the quota laws set by international leaders, such as Norway, since 2003. Fourth, the recommendation was made in response to, and fits comfortably within, the structure of Australia's voluntary regime (implemented via the 2010 Amendments to the ASX Corporate Governance Principles and Recommendations).

\footnotetext{
181 Elizabeth Broderick, Cassandra Goldie and Elena Rosenman, 2010 Gender Equality Blueprint (June 2010) Australian Human Rights Commission, 5 $<$ http://www.humanrights.gov.au/sites/default/files/document/publication/Gender_Equality_B lueprint.pdf $>$.

${ }^{182}$ Ibid.

${ }^{183}$ Ibid $1-7$.

${ }^{184}$ Ibid 5.

185 Ibid.

${ }^{186}$ Armstrong and Walby, above n 5, 30-1.
} 
Fifth, the proposed timeframe (five years) is comparable with quota legislation timeframes implemented in other nations - including Norway ${ }^{187}$ and France ${ }^{188}$ — providing a realistic benchmark against which the progress of Australia's voluntary regime can be assessed. Sixth, the recommendation takes Australia's voluntary regime one step further in that it quantifies the measurable objectives as targets, in a manner consistent with international leaders, and it sets a reasonable timeframe for the targets to be met. In doing so, the Australian Human Rights Commission encourages Australian companies to commit to targets and achieve them.

Last, it is sometimes argued that the adoption of legislated quotas is considered to be one board gender diversity mechanism that can achieve best practice targets. ${ }^{189}$ Structuring a voluntary mechanism with quantifiable targets comparable to those legislated in other nations is an effective method of benchmarking Australian progress. ${ }^{190}$ For the benefits of a voluntary regime to be enjoyed by the Australian economy, there must be evidence that it is an effective alternative to legislation. The Australian Human Rights Commission recommendations certainly progress the voluntary regime further than the ASX Corporate Governance Principles and Recommendations alone.

As of April 2011, Broderick considered that Australia needed to attain the following targets to achieve 40 per cent female representation on publicly listed boards by the end of 2015: 17 per cent by the end of 2011; 25 per cent by the end of 2012; 30 per cent by the end of 2013; 35 per cent by the end of 2014; and a minimum of 40 per cent by the end of $2015 .{ }^{191}$ As at 28 May 2014, ASX 200 boards had increased female directorships to 15.7 per cent. ${ }^{192}$ However, this improvement still trails the Australian Human Rights Commission's 2011 year-end target by 1.3 per cent, the 2012 year-end target by 9.3 per cent, and the 2013 year-end target by 14.3 per cent. ${ }^{193}$ Obviously, progress may occur at different rates. However, it is important to track performance in order to identify shortcomings.

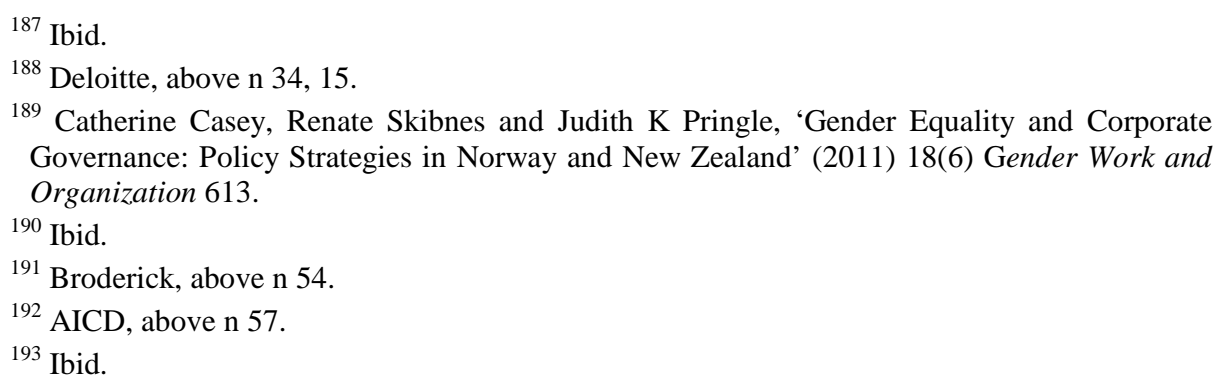




\section{ARE There Grounds for Optimism in Australia?}

As at January 2012, there were 64 ASX 200 companies (32 per cent of the ASX 200) without one female board member, while 41 of the ASX 200 boards did not have any women by 28 May 2014, representing a percentage of 20.5 per cent. ${ }^{194}$ The progress seems steady for listed companies, but it should be pointed out that some not-for-profit organisations and universities demonstrate much higher female governance representation. ${ }^{195}$ In fact, research conducted in 2008 by a group of leading women called 'Women on Boards' revealed that women held 30 per cent of the directorships on Australia's top not-for-profit organisations (by revenue), and, as early as 2004, more than 75 per cent of not-for-profit organisations had female board members. ${ }^{196}$ Furthermore, as early as 2008, female governance representation among the 'Group of Eight' universities was at levels equal to those achieved by Norway's corporate sector in 2012 (36.8 per cent). ${ }^{197}$ As at 30 June 2012, women comprised 38.4 per cent of government board positions, assuming 41 per cent of the new appointments during the 2011/2012 financial year. ${ }^{198}$ Government, not-for-profit organisations and university appointments, which demonstrate much higher female governance-level representation, are encouraging. Nevertheless, it should be clear that, despite the noted improvement and clear potential, Australia has 'a long way to go'. ${ }^{199}$

The 2010 amendments to the ASX Corporate Governance Council's Corporate Governance Principles and Recommendations that required board diversity policies or an explanation why one was not adopted (under the 'if not, why not' principle) provided an impetus for an immediate improvement in the number of female appointments to ASX 200 directorships, and represented a milestone in Australia's pursuit of best practice targets through a voluntary mechanism. As can be seen from Figure 1, immediate results

\footnotetext{
${ }^{194}$ Gladham and Lamb, above n 142.

${ }^{195}$ AICD, above n 57.

${ }^{196}$ Ibid.

${ }^{197}$ Ibid.

198 This progress suggests the government is on track to achieve its target of $40 \%$ women and 40\% men on its boards by 2015: Australian Government Department of Families, Housing Community Services and Indigenous Affairs, Gender Balance on Australian Government Boards Report 2011-2012 (15 November 2012) Australian Government Department of Social Services <http://www.fahcsia.gov.au/our-responsibilities/women/publications-articles/genderbalance-on-australian-government-boards-report-2011-2012>.

${ }^{199}$ AICD, above n 57.
} 
followed after the amendments and it created optimism that Australia's push to voluntarily achieve best practice targets among its listed companies would be effective.

\section{Figure 1}

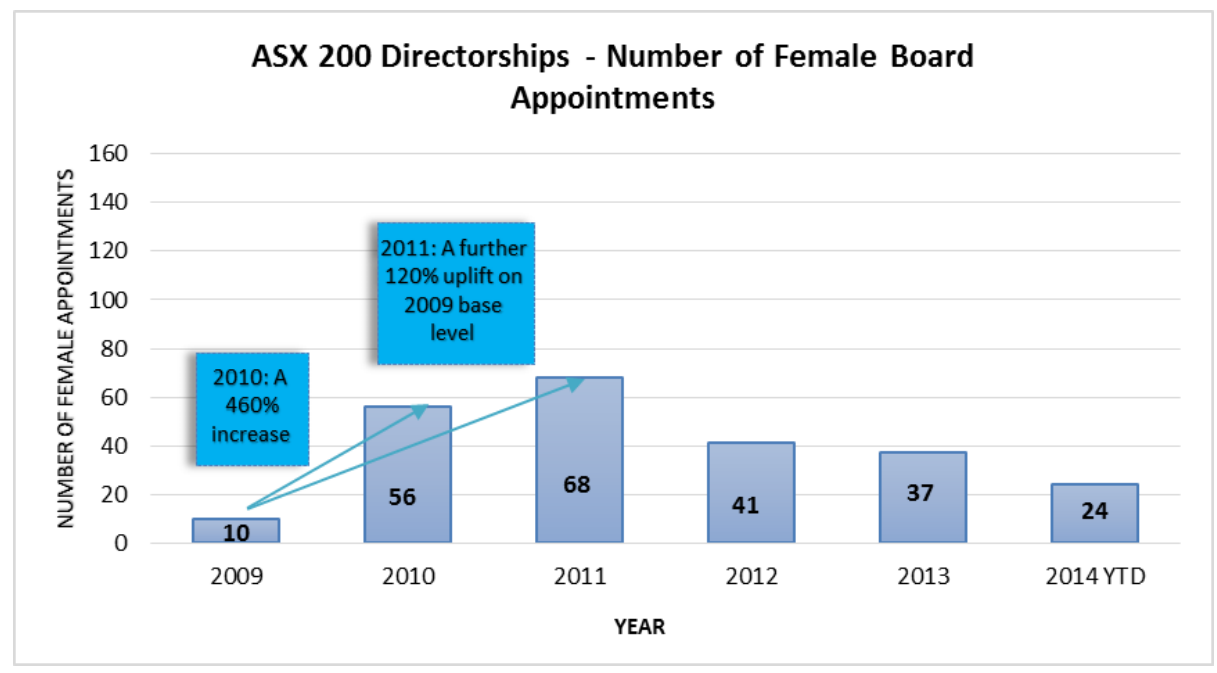

* Source: Figure developed from publicly available data from the AICD webpage.

** YTD for 2014 was 28 May 2014, which indicates a projected 57.6 female appointments for 2014.

As will be apparent from Figures 1 and 2, ASX 200 companies have rarely appointed female directors prior to 2010, when the ASX's Corporate Governance Principles and Recommendations were amended. ${ }^{200}$ Only 5 per cent of new appointments in 2009 were women, preceded by 8 per cent in both 2008 and 2007. ${ }^{201}$ In 2010, female appointments increased 460 per cent and, in 2011, they rose a further 120 per cent (on the 2009 base level). After the rapid increases of 2010 and 2011, new female directorships as a percentage of total new board appointments have decreased among ASX 200 companies to 22 per cent in both 2012 and 2013. ${ }^{202}$ Although the combined increase of 580 per cent on 2009 base level figures during 2010 and 2011 is

\footnotetext{
${ }^{200}$ ASX Corporate Governance Council, Governance Principles, above n 127.

${ }^{201}$ AICD, above n 57.

${ }^{202}$ Ibid.
} 
striking, further investigation reveals a more sobering underlying reality. In 2009, 10 females represented 5 per cent of all appointments to ASX 200 company boards (10 women compared to 190 men, for a total of 200 new appointments). In 2010, 56 females represented 25 per cent of total new appointments (56 women compared to 168 men for a total of 224 new appointments), and in 2011, 68 females represented 28 per cent of the total (68 females compared to 174 males for a total of 242 new appointments). Figure 2 illustrates the gender gap in new appointments to ASX 200 company boards over recent years.

\section{Figure 2}

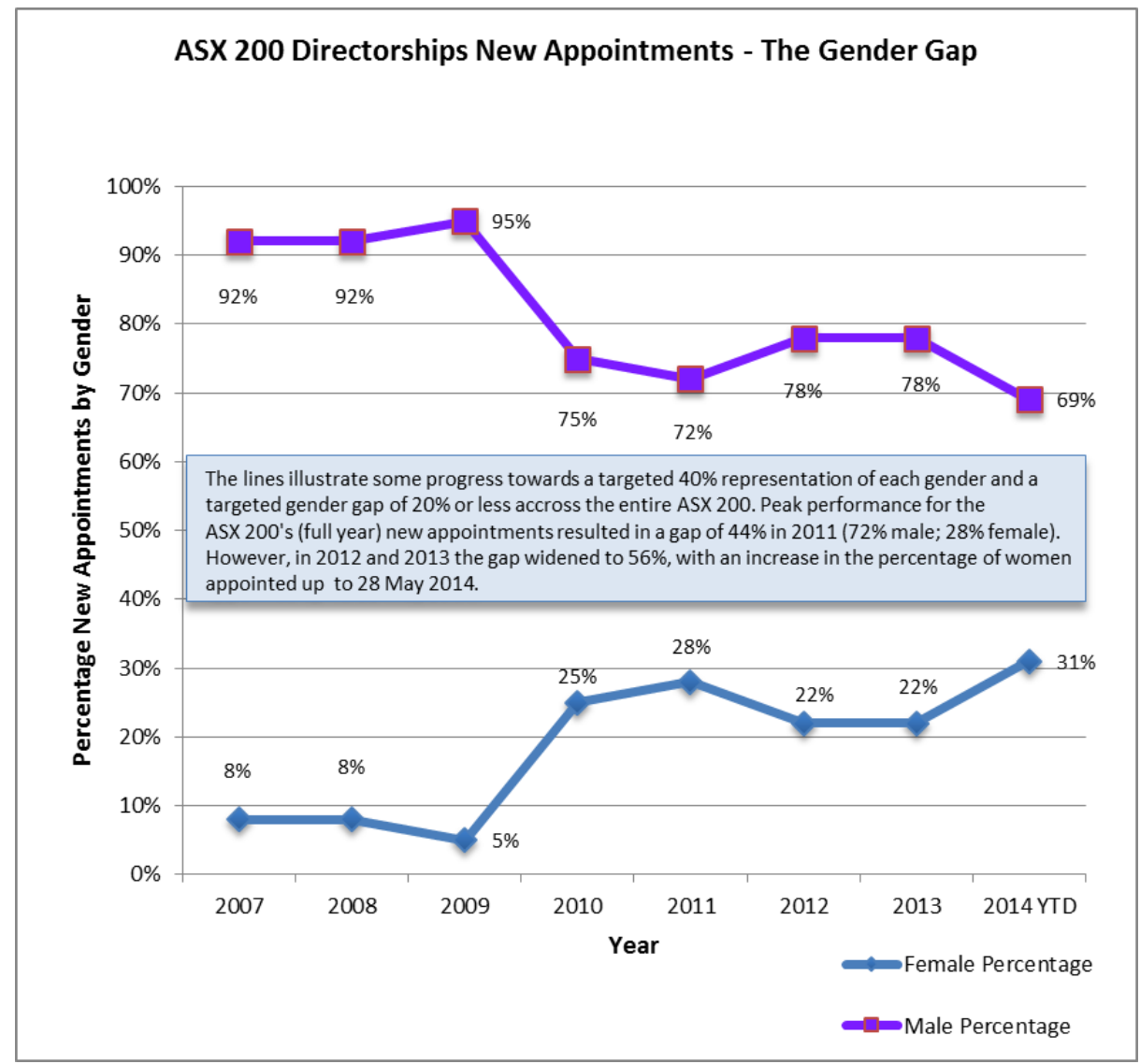

* Source: Figure developed from publicly available data from the AICD webpage. 
An issue of concern is that, despite improvement, Australia is a long way from reaching best practice targets - even among its new appointments. To achieve a minimum representation of 40 per cent for each gender across the entire ASX 200, new appointments and existing seats would need to be distributed between genders in the targeted proportion. To remove male directors from existing seats in favour of females would initially seem difficult and contrary to the spirit of a voluntary system. The making of new appointments, however, provides an opportunity for ASX 200 companies to alter gender balance with more ease and flexibility. Despite that opportunity, as is clear from Figure 2, the ASX 200's new appointments have fallen short of best practice targets every year. Increasing new female appointments to targeted levels alone will not achieve best practice levels across the entire ASX 200. Indeed, fewer than 10 per cent of ASX 200 director seats turn over annually; ${ }^{203}$ the effect of new female appointments is diluted in instances where retired seats have been held by other females. Bringing the number of new female appointments to best practice levels is the next step. Despite its necessity, however, meeting best practice criteria alone will be insufficient to achieve the desired targets within reasonable timeframes.

\footnotetext{
${ }^{203}$ Laurence Lock Lee, 'Are Board Turnover Rates Limiting Diversity Opportunities and Growth?' in Laurence Lock Lee, Governance in a Networked World (14 January 2013) $<$ http://blog.optimice.com.au/?p=111>.
} 


\section{Figure 3}

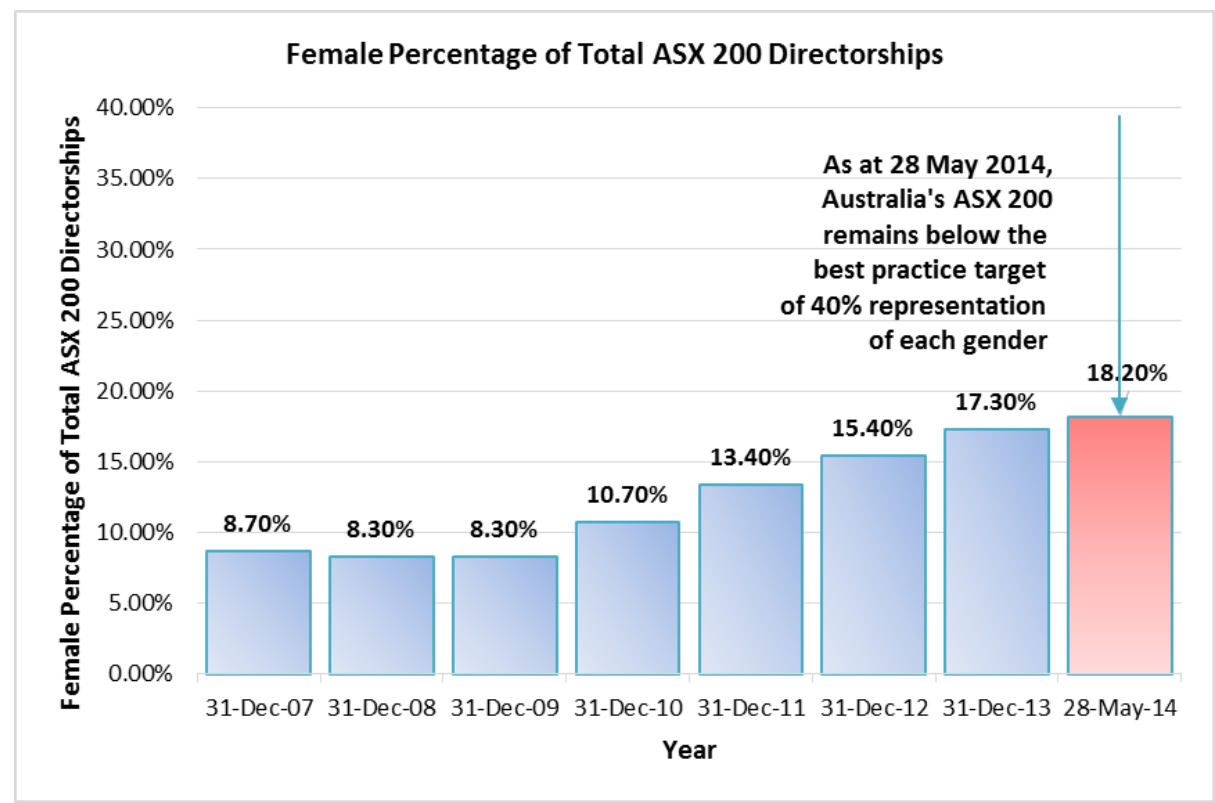

* Source: Figure developed from publicly available data from the AICD webpage.

** YTD 2014 is 28 May 2014, which indicates a projected 43.68 female appointments for 2014.

Figure 3 indicates that, despite the striking 580 per cent uplift in female appointments during 2010 and 2011, the real percentage of female directors across the entire ASX 200 increased only 5.1 per cent (from 8.3 per cent at the start of 2010 to 13.4 per cent by the end of 2011). Remarkable (percentage) increases in new female appointments effected minor increases in female representation across the ASX 200 for two reasons. First, starting from a low base in 2009, minor improvement resulted in substantial percentage increases, thus overstating performance. Second, new female appointments are overshadowed by an already male dominated ASX 200. With ASX 200 companies averaging 7.7 directors each, there are approximately 1540 directorships within the ASX $200 .{ }^{204}$ The addition of 124 new female

${ }^{204}$ Ibid. Clearly, the annual rate of ASX 200 vacancies varies considerably. In 2010, 56 women represented 25 per cent of new ASX 200 appointments, amounting to 224 seats turned over (56/0.25). In 2011, 68 women represented 28 per cent of total new appointments, for a total of 243 (68/0.28) seats turned over: AICD, above n 57. 
directorships during 2010/2011 (56 in 2010 and 68 in 2011) only increased female representation to 13.4 per cent of all ASX 200 company boards (a real increase of only 5.1 per cent over two years, at an average of $2.55 \%$ per year). In the following two years and four months to 28 May 2014, the real percentage increase of ASX 200 directorships held by women has slowed down (rising only 4.8 per cent to 18.2 per cent, at an average of $1.98 \%$ per year).

\section{Figure 4}

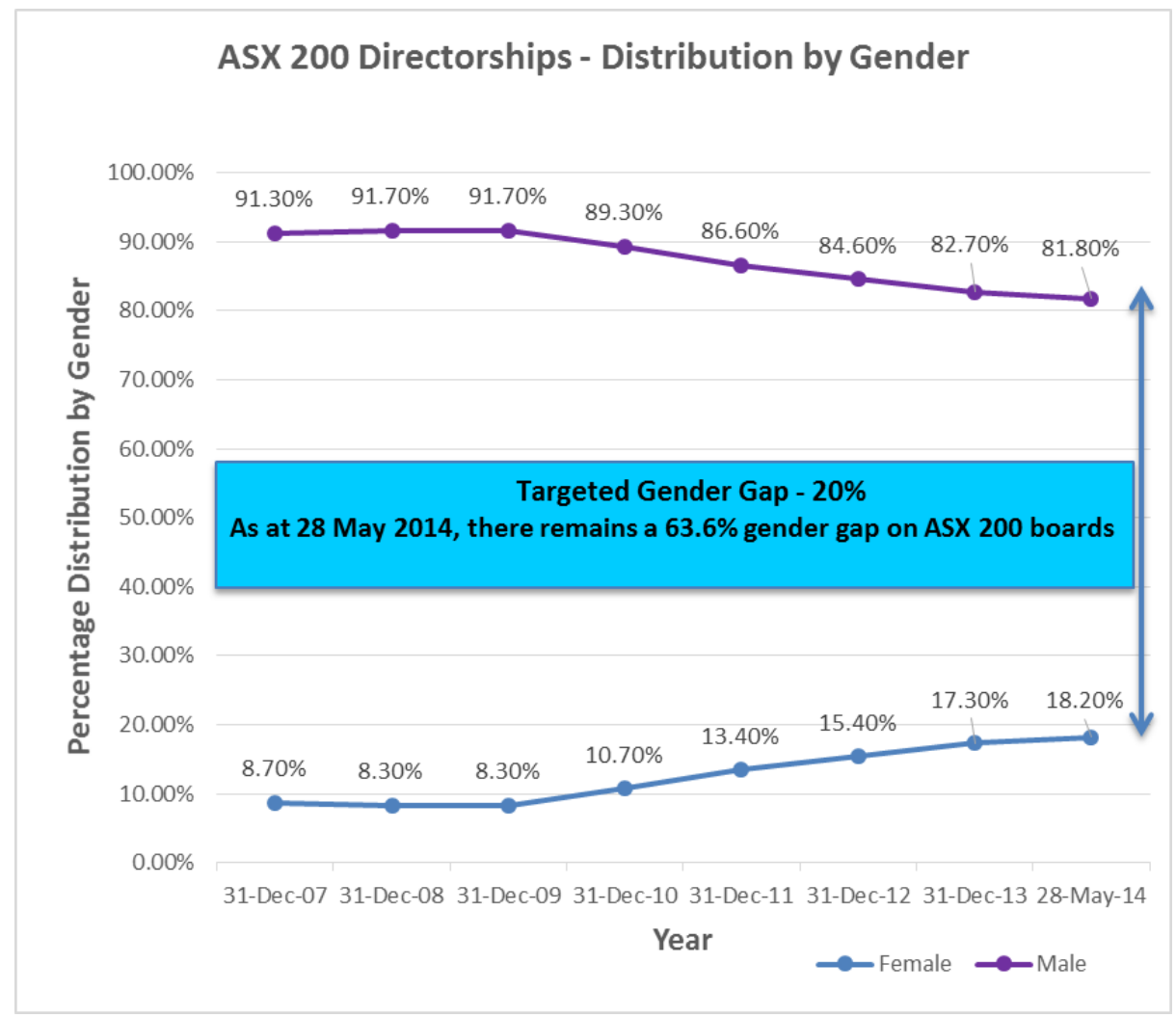

* Source: Figure developed from publicly available data from the AICD webpage.

** YTD 2014 is 28 May 2014, which indicates a projected 43.68 female appointments for 2014. 
Figure 4 indicates that the percentage of females across the entire ASX 200 increased 2 per cent in 2012 to 15.4 per cent and a further 1.9 per cent to 17.3 per cent by 31 December 2013. During the five months to 28 May 2014, an additional 24 women have been appointed to ASX 200 boards, pushing female representation up to 18.2 per cent — the highest in Australia's history — and reducing the gender gap to 63.6 per cent.

In almost four and a half years - from 1 January 2010 to 28 May 2014 Australia has increased the real percentage of female directors across the ASX 200 by 9.9 per cent (from 8.3 per cent to 18.2 per cent). When presented as a percentage increase (119.3 per cent) ${ }^{205}$ this result is impressive. Combined with the previously discussed statistics, these improvements may suggest deceptively rapid progress towards best practice targets, which may reduce pressure on and scrutiny of ASX 200 companies' board gender diversity in the short term. However, when the statistical perspective is switched to what remains to be achieved, the underlying reality becomes clearer.

In order to achieve 40 per cent representation of both genders on ASX 200 company boards, Australia must further increase real female representation across the entire ASX 200 by 21.8 per cent. In order to achieve this target, within the five-year time period adopted in numerous jurisdictions and hence to justify the voluntary mechanism as a true equivalent to mandatory quotas, the real average annual rate of increase achieved over the past four and a half years (9.9 per cent, or an average of 2.2 per cent per year) would need to be increased by more than a factor of 20 in the next six months. At the current rate of progress (9.9 per cent over four and a half years), it will take Australia another 9.9 years to achieve 40 per cent female representation, with the target being achieved some time in mid-2024.

In order to meet the 40 per cent target from current levels (28 May 2014), women must be appointed to nearly one-quarter (21.8 per cent) of all board positions across the entire ASX 200, without any currently serving female directors relinquishing their positions to males. However, ASX 200 boards have an average of 7.7 directors with a turnover rate of 10.7 per cent, which provides only 165 directorship vacancies per year. ${ }^{206}$ Given that there are

\footnotetext{
${ }^{205}$ This is calculated as [(18.2-8.3)/8.3*100].

206 The turnover rate and average vacancies per year are based upon research performed by Governance in a Networked World. Board turnover rates were determined by measuring 'year-to-year changes in board memberships since 2004'. It was noted that '[o]f the 539 companies listed for the full period, 212 have on average 10.2\% turnover. 25 companies had
} 
1540 ASX 200 directors, women must be appointed to an additional 336 seats (21.8 per cent of 1540) to meet the minimum 40 per cent target for each gender (assuming the composition of ASX 200 board seats remains at 1540).

For Australia to reach this target within a reasonable timeframe (the end of 2015 has been suggested as reasonable) — with only 165 vacancies available per year - every single appointment would need to be female for the remainder of 2014 (96 seats) and for all of 2015 (165 seats), plus 75 presently serving male directors would need to be replaced by women. We can confidently predict that that this will not occur. Indeed, it has been postulated that the best-case scenario under a voluntary mechanism is to anticipate women being appointed to a maximum of 25 per cent of directorship vacancies, ${ }^{207}$ meaning that it would take a further nine years to achieve 40 per cent representation of both genders. ${ }^{208}$ However, it is important to note a statistical reality: the recruitment of females at a rate of 25 per cent of total new appointments only increases female representation across the entire ASX 200 because women currently hold less than 25 per cent of all seats. Once the ASX 200 achieves 25 per cent female representation (and assuming that director seats are retired proportionately to their appointment), allocating 25 per cent of new seats to women will only maintain that level. As the achievement of 'critical mass' will render further progress uncertain, so too, will the 25 per cent ceiling present an obstacle that must be negotiated if Australia is to make its voluntary system succeed.

A voluntary regime would require ASX 200 companies to terminate large numbers of male directors and replace them with females in order to achieve the same results as a mandatory regime within a reasonable timeframe. This may seem an extreme measure and unlikely to be implemented. In order for a voluntary regime to achieve the same results as a mandatory regime, it is an option that needs to be considered seriously. The general criticisms of the voluntary system are that it is 'slow' and achieves 'small' reductions in

experienced no changes at all over the 8-year period. Of the 1,652 companies listed for more than 12 months, the average annual turnover is just 13\%, and for the ASX200 10.7\%': Lee, above $n 203$.

207 Ibid. The ACSI anticipates that 40 per cent representation of each gender will not be achieved at current rates until 2030: Alembakis, above n 179.

${ }^{208}$ Lee, above n 203. Below the ASX 200, where female participation falls, it is anticipated that this will take 13 years to achieve. 
gender imbalance at board level. ${ }^{209}$ The challenge is immense; the rewards are great, but the risks are real.

As more nations implement quota legislation and progress towards best practice targets, Australia will face greater political pressure to report comparable statistics. Australian companies must redress gender imbalance or risk losing the benefits of a voluntary system. International comparisons with Australia's progress over coming years will be intriguing, as more nations roll out quota legislation.

\section{iX SOME TREndS ANd Concluding OBSERVATIONS}

\section{A Holistic Approach to Board Diversity in the International Context}

Nations aiming to achieve board level diversity should be alert to the benefits of holistic approaches, which may help to achieve sustainable reductions in gender imbalance. Specifically, the design and implementation of collaborative push and pull strategies in conjunction may help to realise such objectives. Simply setting quota legislation targets and 'pulling' minority groups onto boards to satisfy reporting requirements risks corporate performance suffering under the governance of unqualified, inexperienced directors. Such an occurrence would be detrimental to long-term board diversity and equality. By comparison, the development of expertise and qualifications in individuals from all (diverse) talent pools provides a better opportunity for directorship success; it supports improved corporate performance and hence reinforces diverse director appointments.

The 'right [board-level] gender balance' can be achieved through the recruitment of an appropriate mix of well-qualified directors from all talent pools, with a view to furthering a corporation's objectives. ${ }^{210}$ This method acknowledges 'gender' within the broader context of diversity. ${ }^{211}$ Corporate Australia is being encouraged to embrace such an approach, and gender diversity has, since 2010, been a prominent feature of the voluntary corporate

\footnotetext{
${ }^{209}$ Armstrong and Walby, above $\mathrm{n} 5$.

${ }^{210}$ CAMAC, above n 34, 51.

${ }^{211}$ Ibid.
} 
governance regime applicable to ASX listed companies. ${ }^{212}$ The use of such an approach follows its success in the government sector and some not-for-profit sectors in Australia.

Some scholars correlate board diversity with corporate performance; gender imbalance spawns social inequity and disparate participation levels. Hence, it is imperative that Australian board and senior executive diversity continues to increase. The ASX Corporate Governance Council argues that companies and countries that are able to use all talent will be better placed to achieve global (and local) success, whilst enjoying the benefits of greater equality. ${ }^{213}$ In order to reduce board gender imbalance, strategies addressing the underlying causes of the imbalance need to be implemented, and rates of progression towards equality achieved in recent years need to be maintained.

\section{B Not-for-Profit and Government Experience}

In the not-for-profit and government sectors in Australia, a range of methods has been used to achieve greater board diversity. They have included policy change; coalitions of support from experienced male corporate board directors, with experienced business and government board members acting together; and changes in the organisational culture of certain types of not-forprofit organisations. Elizabeth Broderick has noted that the barriers to the equitable progression of women in the workplace fall into three categories, which broadly correlate to the argument about the need for change in the outer and inner context and through content. These barriers are:

(a) belief barriers - deeply held cultural beliefs such as the good mother stereotype, the ideal worker stereotype (content);

(b) cultural barriers - selection, promotion and career development systems which disadvantage women (inner context); and

\footnotetext{
${ }^{212}$ ASX Corporate Governance Council, Governance Principles, above n 127.

${ }^{213}$ Promoting gender equity at board level would further improve the economic equality between the sexes. 'It's worth noting that greater economic equality between men and women has been shown to reduce poverty rates, boost GDP and lead to better governance. In order to improve female participation rates, governments can adopt a number of proven approaches such as flex-time initiatives, free or subsidized childcare, and tax breaks for married couples when both partners work': Forbes Insights, above n 34, 8.
} 
(c) structural barriers - the lack of affordable childcare, no paid parental leave scheme ${ }^{214}$ (outer context).

With mandatory regimes, it has been proven that corporate boards in those countries having adopted them can achieve targeted levels of gender representation. Following the argument through, if targeted voluntary levels are 'equitable' then the 'right gender balance' may be achieved.

\section{Mandated Quotas Will Achieve Results, but Is It the Desirable Method?}

Mandated quota legislation in countries such as Norway has achieved gender diversity. Norway is the country with the highest participation of women at board level (36 per cent), the result of mandating a quota system for publicly listed companies. ${ }^{215}$ However, the pressure of legal sanctions may lead to inappropriate directorship appointments. Further, legal sanctions may alienate those who might otherwise champion change for greater board diversity. It was reported in Norway in $2012^{216}$ that around 70 female managers share 300 board positions among themselves. ${ }^{217}$ They have been nicknamed 'golden skirts'. ${ }^{218}$ This development is viewed with scepticism, especially considering the potential conflicts of interest associated with membership on multiple boards. ${ }^{219}$ There is a risk that Australia may follow this pattern, particularly among the ASX 200 where 164 women currently hold 230 directorships (equating to 28 per cent of women having multiple directorships). ${ }^{20}$ The higher level of concentrated participation by females has been expressed as a concern, with 'females by far having more multiple board memberships'. 221

\footnotetext{
${ }^{214}$ Broderick, above n 54 .

${ }^{215}$ Forbes Insights, above n 34, 10.

${ }^{216}$ See Du Plessis, Saenger and Foster, above n 49, 247.

${ }^{217}$ Commentary, 'Goldröcke und Großmütter an der Macht', FAZ, 15 February 2011 (Nr 38), 18.

${ }^{218}$ See Mark Lewis, 'Most of the Women Who Make up Norway’s “Golden Skirts” Are NonExecs', The Guardian (online), 1 July 2011 <http://www.theguardian.com/ business/2011/jul/01/norway-golden-skirt-quota-boardroom>.

${ }^{219}$ Gerd Krieger, 'Keine gesetzliche Frauenquote für Aufsichtsräte' (2011) 61 Anwaltsblatt 918.

${ }^{220}$ Alembakis, above n 179.

${ }^{221}$ Laurence Lock Lee, ‘The 'Sisterhood’ Goes Missing at Board Level’ in Lee, above n 203.
} 


\section{Significant Progress without Mandatory Quota Legislation}

Initiatives introduced through the ASX Corporate Governance Principles and Recommendations are astute and have driven substantial improvement. ${ }^{222}$ Fair and ethical remuneration, the promotion of a culture of female participation, the provision of sufficient induction, training and education for new directors, commitment to diversity policy, and the establishment of transparent board appointment procedures with a focus on considering all talent sources, are just some actions introduced through the 2010 amendments to the ASX Corporate Governance Principles and Recommendations. ${ }^{223}$ Other actions which might be pursued include extending the mentoring of potential female directors by experienced directors; the mentoring of women by men in CEO positions; the provision of a voice for change for women through peak bodies, such as Women on Boards; and the lobbying of government for change in the corporate sector, as has occurred in the government and some parts of the notfor-profit sectors.

Despite the apparent success of Australia's voluntary regime, the test of its substance will arise in coming years. Australian corporate governance will face challenges in pushing beyond the point of 'critical mass' and closing the gap between the current level of 15.8 per cent female board participation and best practice ( 40 per cent) in the face of competition from countries which have enacted legislative quotas.

Australia has a strong voluntary strategy, which is arguably preferable to legislation. Both the government sector and parts of the not-for-profit sector provide lessons on how to achieve board diversity in its broadest sense in a voluntary regime. Driven by a desire for continuous improvement, by women taking individual action in their careers, ${ }^{224}$ by powerful men who support

\footnotetext{
${ }^{222}$ As discussed further above, the improvement noted following the introduction of the ASX Corporate Governance Council's Corporate Governance Principles and Recommendations with 2010 amendments was immediate and substantial. Although commencing from a low base and despite leaving much work still to complete, the voluntary mechanism has achieved a substantial improvement.

${ }^{223}$ ASX Corporate Governance Council, Governance Principles, above n 127, 6.

${ }^{224}$ Sheryl Sandberg, COO of Facebook, is one female leader who has advocated for women to '[take] more control of their careers': Sheryl Sandberg, Why We Have too Few Women Leaders (December 2010) TED <http://www.ted.com/talks/lang/en/sheryl_sandberg _why_we_have_too_few_women_leaders.html> (by interview) in Grant Thornton, above $\mathrm{n}$ 178, 11. In her speech, Sandberg noted that what the data shows, above all else, is 'that success and likeability are positively correlated for men and negatively correlated for
} 
women seeking board positions, and by a changing attitude in corporate Australia to female participation, board equality is achievable.

\section{Overall Summary and Conclusions}

This article has analysed Australian board diversity, in an international context, with particular emphasis upon gender. Although gender represents but one element of board diversity, over the past decade it has been the subject of substantial international scrutiny, debate and political action, making it certainly the most topical. The correlation between board gender diversity and enhanced corporate performance is supported by empirical research. The authors have pointed out that this correlation is subject to numerous counter-arguments; however, there is a very widely held view that gender diversity is a matter of good corporate governance even if it is still inconclusive whether there is a business case to be made out for including a certain percentage of males or females on boards. The board gender debate has inspired change, providing a solid foundation upon which the international community - corporate and non-corporate - can improve performance in all elements of board diversity.

The change process has evolved through several phases, which were outlined in an historical framework. As the debate has progressed, international best practice targets have developed, with nations implementing various mechanisms, policies and laws to contribute domestically to the amelioration of a global issue. These mechanisms possess unique advantages and disadvantages, with the practical implementation of each achieving change by varying degrees of speed and magnitude. Similarly, each mechanism exposes its nation to unique and specific risks - a fact which may be overlooked in the rush to improve statistics.

Norway is the proven international leader, achieving best practice among its listed companies by enacting mandatory quota legislation. In response, numerous countries have followed Norway's lead by introducing their own

women'. Whilst not suggesting that women be rude and unlikeable in the workplace, she noted the workplace challenges that might explain why a smaller percentage of women than men reach the top of their professions. Creating the opportunity and encouraging participation, whilst removing barriers to female career development, are essential processes. Coupled with a drive from women - a belief that they deserve as much as men any promotion, opportunity or progression for which they are equally qualified — will lead to a multi-faceted approach that will decrease the imbalance. 
quota legislation. However, critics of this measure argue that quota legislation results in window dressing and presents risks to the integrity and strength of corporate governance. Certainly, the ideal scenario is for organisations to voluntarily achieve board gender equality, thereby retaining discretion over directorship appointments, and avoiding compliance costs and penalties whilst committing to a culture of gender equity by choice. However, in the corporate world, voluntary mechanisms have achieved slower and less significant results. For such mechanisms to be successful, it is essential to push beyond the tipping point, within reasonable timeframes, to achieve board gender diversity.

Australian progress towards best practice targets has improved (from a low base) since the 2010 introduction of the ASX Corporate Governance Council's amendments to Corporate Governance Principles and Recommendations. However, statistics place Australia behind global leaders. This article has analysed mechanisms used to improve board gender diversity and Australia's progress towards best practice. Furthermore, an assessment has been made of the opportunity that exists for Australia to become the first nation to achieve best practice in its corporate sector using a voluntary strategy. It is evident that, in doing so, much can be learnt from other nations and from the Australian not-for-profit, university and government sectors. 


\section{APPENDIX}

\section{Table 1: Overview of Development of Board Gender Diversity in Australia: Context and Content 1970-2013}

\begin{tabular}{|c|c|c|c|}
\hline \multirow{5}{*}{$\begin{array}{l}\text { 1970-1982: } \\
\text { Equal Rights }\end{array}$} & Content & Outer Content & Inner Content \\
\hline & $\begin{array}{l}\text { 1970: Direct action by } \\
\text { women as individuals } \\
\text { and organised groups. }\end{array}$ & $\begin{array}{l}\text { 1972: Whitlam Labor } \\
\text { government elected. }\end{array}$ & $\begin{array}{l}\text { 1970: Germaine Greer's } \\
\text { The Female Eunuch } \\
\text { published. }\end{array}$ \\
\hline & $\begin{array}{l}\text { 1972: Australian } \\
\text { Conciliation and } \\
\text { Arbitration Commission } \\
\text { adopted the principle of } \\
\text { equal pay for work of } \\
\text { equal value. }\end{array}$ & $\begin{array}{l}\text { 1975: Racial } \\
\text { Discrimination Act } \\
\text { and Sexual } \\
\text { Discrimination Act } \\
\text { enacted in South } \\
\text { Australia, } \\
\text { International Women's } \\
\text { Year. }\end{array}$ & $\begin{array}{l}\text { 1972: Women’s } \\
\text { Electoral Lobby } \\
\text { founded. }\end{array}$ \\
\hline & $\begin{array}{l}\text { 1973: First Women's } \\
\text { Advisor to the Prime } \\
\text { Minister, the first such } \\
\text { position in the world. }\end{array}$ & $\begin{array}{l}\text { 1977: First Victorian } \\
\text { Equal Opportunity Act } \\
\text { enacted. }\end{array}$ & \\
\hline & $\begin{array}{l}\text { Educational direct action } \\
\text { to provide girls with } \\
\text { equal educational } \\
\text { opportunities to boys. }\end{array}$ & $\begin{array}{l}\text { 1981: Federal Human } \\
\text { Rights Commission Act } \\
\text { enacted. }\end{array}$ & \\
\hline \multicolumn{4}{|l|}{$\begin{array}{l}\text { 1983-2006: } \\
\text { Workplace } \\
\text { Equality } \\
\end{array}$} \\
\hline & $\begin{array}{l}\text { 1983: Appointment of } \\
\text { first Equal Opportunity } \\
\text { Commissioner. }\end{array}$ & $\begin{array}{l}\text { 1983, 1987, 1990: } \\
\text { Hawke Labor } \\
\text { government elected. }\end{array}$ & $\begin{array}{l}\text { 1987: Affirmative action } \\
\text { pilot programs in major } \\
\text { corporations. }\end{array}$ \\
\hline & $\begin{array}{l}\text { 1987: Persuasion by } \\
\text { government and industry } \\
\text { partnerships for piloting } \\
\text { change programs. } \\
\text { Training programs on } \\
\text { equal opportunity in the } \\
\text { workplace }\end{array}$ & $\begin{array}{l}\text { 1983: Federal } \\
\text { government policy to } \\
\text { appoint women to } \\
\text { government boards. }\end{array}$ & $\begin{array}{l}\text { 2001: Women on Boards } \\
\text { started as an informal } \\
\text { network, incorporating } \\
\text { in } 2006 \text {. }\end{array}$ \\
\hline & $\begin{array}{l}\text { 1987: Public programs } \\
\text { by leading CEOs on } \\
\text { workplace equality }\end{array}$ & $\begin{array}{l}\text { 1984: Sex } \\
\text { Discrimination Act } \\
\text { enacted. }\end{array}$ & $\begin{array}{l}\text { 2002: Workplace Gender } \\
\text { Equality Agency Index } \\
\text { Report. }\end{array}$ \\
\hline
\end{tabular}




\begin{tabular}{|c|c|c|c|}
\hline & Content & Outer Content & Inner Content \\
\hline & $\begin{array}{l}\text { 2007: 40-40-20 rule } \\
\text { introduced in aggregate: } \\
\text { federal government } \\
\text { policy of } 40 \text { per cent } \\
\text { minimum representation } \\
\text { on boards in aggregate } \\
\text { across government } \\
\text { sector. }\end{array}$ & $\begin{array}{l}\text { 1986: Australian Human } \\
\text { Rights Commission Act } \\
\text { enacted. }\end{array}$ & $\begin{array}{l}\text { 2005: Broadened } \\
\text { understanding of } \\
\text { diversity through } \\
\text { CAMAC definition. }\end{array}$ \\
\hline & & $\begin{array}{l}\text { 1992: Disability } \\
\text { Discrimination Act } \\
\text { enacted. }\end{array}$ & \\
\hline & & $\begin{array}{l}\text { 1993: Keating Labor } \\
\text { government elected. }\end{array}$ & \\
\hline & & $\begin{array}{l}\text { 1986: Federal } \\
\text { Affirmative Action for } \\
\text { Women Act enacted, } \\
\text { administered by the } \\
\text { Affirmative Action } \\
\text { Agency. }\end{array}$ & \\
\hline \multicolumn{4}{|l|}{$\begin{array}{l}\text { 2007-Present: } \\
\text { Female Power and } \\
\text { Influence }\end{array}$} \\
\hline & $\begin{array}{l}\text { 2007: Political action } \\
\text { through elections. }\end{array}$ & $\begin{array}{l}\text { 2007: Rudd Labor } \\
\text { government elected. }\end{array}$ & $\begin{array}{l}\text { 2007: ASX Revised } \\
\text { Corporate Governance } \\
\text { Principles and } \\
\text { Recommendations: } \\
\text { mandatory gender } \\
\text { reporting guidelines. }\end{array}$ \\
\hline & $\begin{array}{l}\text { 2010: } 40-40-20 \text { rule } \\
\text { introduced for each } \\
\text { board: Federal } \\
\text { government policy to } \\
\text { have } 40 \text { per cent } \\
\text { minimum representation } \\
\text { of men and women on } \\
\text { each government board. }\end{array}$ & $\begin{array}{l}\text { 2010: Gillard Labor } \\
\text { government elected. }\end{array}$ & $\begin{array}{l}\text { 2010: AICD scholarships } \\
\text { and mentoring for } \\
\text { women on boards. }\end{array}$ \\
\hline & $\begin{array}{l}\text { 2012: Workplace Gender } \\
\text { Equality Act enacted. }\end{array}$ & $\begin{array}{l}\text { 2012: Revision of } \\
\text { federal Equal } \\
\text { Opportunity and Sex } \\
\text { Discrimination Acts. }\end{array}$ & $\begin{array}{l}\text { 2011: Male champions } \\
\text { of women on boards, led } \\
\text { by Mike Smith, CEO, } \\
\text { ANZ Bank. }\end{array}$ \\
\hline & $\begin{array}{l}\text { 2013: Leadership action } \\
\text { by agencies and } \\
\text { professional bodies to } \\
\text { broaden diversity on } \\
\text { corporate boards. }\end{array}$ & & $\begin{array}{l}\text { 2012: Census of Women } \\
\text { in Leadership, Equal } \\
\text { Opportunity for Women } \\
\text { in the Workplace } \\
\text { Agency, including data } \\
\text { on women on corporate } \\
\text { boards. }\end{array}$ \\
\hline
\end{tabular}

